\title{
An overview on isotopic divergences - causes for instability of tree-ring isotopes and climate correlations
}

\author{
Martine M. Savard ${ }^{1}$ and Valérie Daux ${ }^{2}$ \\ ${ }^{1}$ Geological Survey of Canada, Natural Resources Canada, Quebec, G1K 9A9, Canada \\ ${ }^{2}$ Laboratoire des Sciences du Climat et de l'Environnement (LSCE/UVSQ/CNRS/CEA/IPSL), Gif-sur-Yvette, 94800, France
}

Correspondence: Martine M. Savard (martinem.savard@ canada.ca)

Received: 18 February 2020 - Discussion started: 6 March 2020

Revised: 10 June 2020 - Accepted: 22 June 2020 - Published: 13 July 2020

\begin{abstract}
Climatic reconstructions based on tree-ring isotopic series convey substantial information about past conditions prevailing in forested regions of the globe. However, in some cases, the relations between isotopic and climatic records appear unstable over time, generating the "isotopic divergences". Former reviews have thoroughly discussed the divergence concept for tree-ring physical properties but not for isotopes. Here we want to take stock of the isotopic divergence problem, express concerns and stimulate collaborative work for improving paleoclimatic reconstructions.

There are five main causes for divergent parts in isotopic and climatic series: (1) artefacts due to sampling and data treatment, relevant for dealing with long series using subfossil stems; (2) stand dynamics, including juvenile effects mostly occurring in the early part of tree-ring series; (3) rise in atmospheric $p \mathrm{CO}_{2}$, which can directly influence the foliar behaviour; (4) change in climate, which may modify the isotope-climate causal links; and finally (5) atmospheric pollution, which may alter leaf and root functions. Future paleoclimate research would benefit from interdisciplinary efforts designed to develop further process-based models integrating multi-proxy inputs so as to help identify causes of isotopic divergences and circumvent some of them in inverse applications.
\end{abstract}

\section{Introduction - divergence, informative but knotty}

Tree-ring isotopes can serve as proxies for climatic parameters for reconstructing past climate variability, which is useful for understanding regional and global climatic patterns (Treydte et al., 2007; Braconnot et al., 2012; Naulier et al., 2015a). In most cases, such reconstructions assume that the observed modern statistical relationship between tree-ring isotopic proxies and measured climatic parameters was identical in the past. Parameters such as ambient temperature, solar radiation and air moisture are also assumed to trigger responses in the biological functions of trees (e.g., stomatal conductance), thus modulating quantifiable tree-ring stable isotopes of carbon $\left(\delta^{13} \mathrm{C}\right)$ and oxygen $\left(\delta^{18} \mathrm{O}\right)$. However, the physiological reactions of trees to changes in environmental conditions do not behave linearly (e.g., Schleser et al., 1999), and several influencing factors may interplay and alternate during the lifetime of a tree. When correlations between climatic parameters and tree-ring proxies show periods of instability such that correlations weaken, become non-significant or change in signs, the relationship between proxies and climatic data shows a "divergence" (D'Arrigo et al., 2008). The concept of the divergence problem first introduced for the offset between ring width and instrumental temperatures of recent decades appears in a large body of literature (e.g., Jacoby and D'Arrigo, 1995; Briffa et al., 1998; D'Arrigo et al., 2008; Esper and Frank, 2009). We refer hereafter to this weakening of the response of tree-ring growth or density to temperature or other climatic parameters as "growth divergence".

Physical characteristics (width, density) and isotopic attributes $\left(\delta^{13} \mathrm{C}, \delta^{18} \mathrm{O}\right)$ of tree rings show distinct sensitivities to climatic and non-climatic conditions (Gagen et al., 2006; Brugnoli et al., 2010; Daux et al., 2011; Savard et al., 2020). When addressing growth-climate relationships, potential causes of growth divergence include moisture stress, complex non-linear or threshold responses, changes in season duration, phenology, and local pollution (D'Arrigo et al., 
2008, and references therein). In addition, detrending ring growth series appears as a methodological potential cause for growth divergence (Esper and Frank, 2009; Esper et al., 2010a). Are those same factors also causing divergence between isotopes and climatic parameters?

The present article deals with "isotopic divergence", which we define here as the middle- to long-term ( $>10$ years) loss or change in signs of correlations between a climatic parameter and tree-ring isotopic ratios $\left(\delta^{13} \mathrm{C}, \delta^{18} \mathrm{O}\right.$ or rarely $\left.\delta^{2} \mathrm{H}\right)$. In this definition, we exclude short-term (high frequency) deviations. Such deviations could derive from insect outbreaks (up to 7 years; Mayfield et al., 2005; Simard et al., 2008; Gori et al., 2014), fungi epidemics (3-4 years; Saffell et al., 2014; Lee et al., 2017), forest clearing, pruning, wind throws and felling (2-7 years of increasing discrimination after thinning; Di Matteo et al., 2010). These brief deviations merely juxtapose with long-term changes in climate variability (low frequency, multi-decadal to multi-centennial). In practice, averaging isotope ratios from several trees and sites smooths out these short-term deviations, which contributes to the uncertainty of the inferred long-term responses.

Isotope-climate divergences per se are rarely discussed in the literature (Aykroyd et al., 2001; Naulier et al., 2015b; Daux et al., 2011). However, several reported cases of nonstationary relationships between climatic parameters and the isotopic proxies altering the efficacy of climate reconstruction models undoubtedly fall under this definition (Table 1). At present, no review on tree-ring isotopes synthesizes the extent and main features of isotopic divergences, although their potential influences on statistical modelling and ensuing climatic reconstructions are clear. One should not ignore that determining periods of isotopic divergence provides key information for understanding climatic patterns and changes in climatic regimes. At the same time, producing unflawed climatic reconstructions requires getting around isotopic divergences.

Given the need for careful assessments of isotopes as climate proxies for various regional contexts and tree species, this synthesis of the up-to-date information on isotopic divergences aims at (1) describing the main isotopic divergence types and discussing their potential causes and (2) reviewing research avenues to identify them and account for them (Table 2).

\section{Mechanisms of tree response to environmental conditions}

\subsection{Control mechanisms for tree-ring isotopes}

The well-accepted equations of Farquhar et al. (1989) describe the main controls on leaf carbon (C) isotopic values $\left(\delta^{13} \mathrm{C}_{\mathrm{L}}\right)$ and their utility in determining the intrinsic water use efficiency (iWUE; the amount of $\mathrm{C}$ acquired per unit of water lost), which equals the ratio of the photosynthetic rate
( $A$ ) to the gaseous conductance $(g)$ as follows:

$$
\begin{aligned}
\delta^{13} \mathrm{C}_{\mathrm{L}} & =\delta^{13} \mathrm{C}_{\mathrm{at}}-\left(a+(b-a) \times c_{\mathrm{i}} / c_{\mathrm{at}}\right), \\
\mathrm{iWUE} & =A / g \\
& =c_{\mathrm{at}} \times\left(b-\delta^{13} \mathrm{C}_{\mathrm{at}}-\delta^{13} \mathrm{C}_{\mathrm{L}}\right) / 1.6 \times(b-a),
\end{aligned}
$$

where $\delta^{13} \mathrm{C}_{\text {at }}$ is the value of atmospheric $\mathrm{CO}_{2}, a$ is the fractionation due to gaseous diffusion of $\mathrm{CO}_{2}$ entering the foliar system via stomata, $b$ is the enzymatic fractionation during the assimilation of $\mathrm{CO}_{2}$ (carboxylation), and $c_{\mathrm{i}}$ and $c_{\text {at }}$ are the intra-foliar and atmospheric pressures of $\mathrm{CO}_{2}$, respectively. Several post-photosynthetic processes can also modify the final $\delta^{13} \mathrm{C}$ values fixed in tree rings through $\mathrm{C}$ exchange with stored carbohydrates (Gessler et al., 2014). However, tree-ring $\delta^{13} \mathrm{C}$ values $\left(\delta^{13} \mathrm{C}_{\mathrm{TR}}\right)$ generally vary in parallel with $\delta^{13} \mathrm{C}_{\mathrm{L}}$ but with an offset (Loader et al., 2003; Verheyden et al., 2005).

The $\delta^{13} \mathrm{C}$ change in atmospheric $\mathrm{CO}_{2}$, which is due to the addition of ${ }^{13} \mathrm{C}$-depleted $\mathrm{CO}_{2}$ from fossil fuel combustion since the beginning of the industrial era (Suess effect), is readily overcome by removing the related isotopic deviation from the $\delta^{13} \mathrm{C}$ series (McCarroll et al., 2009). In this article, we mostly discuss $\delta^{13} \mathrm{C}$ values already corrected for the Suess effect except when providing information on the ecophysiological models that use raw $\delta^{13} \mathrm{C}$ values as input.

Several equations describe the ${ }^{18} \mathrm{O}$ enrichment in leaves due to complex fractionation steps during oxygen $(\mathrm{O})$ assimilation by trees. But a simplified version of these equations (Barbour, 2007) expresses the main controls on the final leaf water ratios $\left(\delta^{18} \mathrm{O}_{\mathrm{f}}\right)$, which include the soil water signal $\left(\delta^{18} \mathrm{O}_{\mathrm{S}}\right)$, relative humidity $(\mathrm{RH})$, the proportion of source water from the roots in leaves $(f)$, equilibrium fractionation factor $\left(\varepsilon^{+}\right)$, kinetic fractionation factor $\left(\varepsilon_{\mathrm{k}}\right)$ and average water and carbonyl group exchange fractionation $\left(\varepsilon_{\mathrm{wc}}\right)$ :

$\delta^{18} \mathrm{O}_{\mathrm{L}}=\delta^{18} \mathrm{O}_{\mathrm{S}}+(1-f) \times(1-\mathrm{RH}) \times\left(\varepsilon^{+}+\varepsilon_{\mathrm{k}}\right)+\varepsilon_{\mathrm{wc}}$.

When dealing with tree-ring $\delta^{18} \mathrm{O}$ cellulose, the dampening factor reflects the proportion of $\mathrm{O}$ exchanged with source water when sucrose is broken down into hexose phosphates during cellulose synthesis, which is allegedly constant in time (Ogée et al., 2009; Cernusak et al., 2016). Hence, processes described in the Craig-Gordon model will influence the final tree-ring cellulose values through the stomatal functions (Roden et al., 2000; Cernusak et al., 2016; Belmecheri et al., 2018).

Any direct or indirect climatic factors operating on the photosynthetic or respiratory functions of trees modify the $A, g, A / g$ ratio or $\mathrm{O}$ fractionation factors (Eqs. 1, 2), and consequently act upon the tree-ring $\delta^{13} \mathrm{C}$ and $\delta^{18} \mathrm{O}$ values. The sensitivity of these proxies to changes in temperature, precipitation, RH and light (cloudiness, radiation) vary with the species of trees, site conditions and regional climate. 
Table 1. Reported critical divergences of correlations between isotopic results and instrumental climatic series (other than sampling, stand dynamics and juvenile effects).

\begin{tabular}{|c|c|c|c|c|c|}
\hline Isotopes & Climate parameters & Tree species & Causes & Region & Author(s) \\
\hline$\delta^{13} \mathrm{C}$ & Summer $T$ & Quercus robur & $\begin{array}{l}\text { CC: longer growth sea- } \\
\text { son }\end{array}$ & Eastern England & Aykroyd et al. (2001) \\
\hline$\delta^{13} \mathrm{C}, \delta^{18} \mathrm{O}$ & Summer $T$, Pc & $\begin{array}{l}\text { Quercus petraea; Pinus } \\
\text { sylvestris }\end{array}$ & $\begin{array}{l}\mathrm{CC} \text { : physiological } \\
\text { adaptation to higher } \\
T \text {, change in moisture } \\
\text { origin }\end{array}$ & Switzerland & Reynolds-Henne et al. (2007) \\
\hline$\delta^{13} \mathrm{C}$ & Summer $T$ & Pinus sylvestris & CC: earlier Summer & Eastern Finland & Hilasvuori et al. (2009) \\
\hline$\delta^{13} \mathrm{C}$ & Summer $T \& \mathrm{Pc}$ & $\begin{array}{l}\text { Quercus robur, Pinus } \\
\text { sylvestris }\end{array}$ & $\begin{array}{l}\text { Poll: } \mathrm{SO}_{2} \text { from close } \\
\text { emitter }\end{array}$ & Southeastern England & Rinne et al. (2010) \\
\hline$\delta^{13} \mathrm{C}$ & Summer cloud cover, $T$ & Pinus sylvestris & $\begin{array}{l}\mathrm{CC}: \mathrm{AO} \text {, decoupling of } \\
T \text { and radiations }\end{array}$ & Northwestern Norway & Young et al. (2010) \\
\hline$\delta^{13} \mathrm{C}, \delta^{18} \mathrm{O}$ & $T_{\max }, \mathrm{RH}$ & Larix decidua & $\begin{array}{l}\text { CC: drier climate, } \\
\text { deeper soil water }\end{array}$ & French Alps & Daux et al. (2011) \\
\hline$\delta^{13} \mathrm{C}, \delta^{18} \mathrm{O}$ & Summer $T \&$ Pc & Pinus sylvestris & $\begin{array}{l}\text { CC: change in } T \text {, irradi- } \\
\text { ance \& cloud circul. }\end{array}$ & N. boreal zone & Seftigen et al. (2011) \\
\hline$\delta^{13} \mathrm{C}$ & Summer $T \& \mathrm{Pc}$ & Larix decidua & Poll: traffic/vehicles & Italian Alps & Leonelli et al. (2012) \\
\hline$\delta^{18} \mathrm{O}$ & Summer Pc & Pinus halepensis & $\begin{array}{l}\text { CC: increase } \\
\text { drought, deeper soil } \\
\text { water }\end{array}$ & Greece & Sarris et al. (2013) \\
\hline$\delta^{13} \mathrm{C}$ & No link & Juniperus virginiana & $\begin{array}{l}\text { Poll: distant } \mathrm{SO}_{2} \text { emit- } \\
\text { ters }\end{array}$ & Appalachians, USA & Thomas et al. (2013) \\
\hline$\delta^{2} \mathrm{H}, \delta^{13} \mathrm{C}, \delta^{18} \mathrm{O}$ & $\mathrm{RH}$ & Abies alba & $\begin{array}{l}\text { Poll: distant } \mathrm{SO}_{2} \text { emit- } \\
\text { ters }\end{array}$ & Southwestern Germany & Boettger et al. (2014) \\
\hline$\delta^{13} \mathrm{C}$ & $\mathrm{RH}, T$ & Abies georgei & $\mathrm{CC}$ : water stress & Western China & Liu et al. (2014) \\
\hline$\delta^{13} \mathrm{C}$ & $T_{\max }$ & $\begin{array}{l}\text { Picea mariana \& } \\
\text { glauca }\end{array}$ & $\begin{array}{l}\text { Poll: oil sands mining } \\
\text { operations }\end{array}$ & Alberta, Canada & Savard et al. (2014) \\
\hline$\delta^{13} \mathrm{C}, \delta^{18} \mathrm{O}$ & Summer $T$, spring Pc & Picea mariana & $\begin{array}{l}\mathrm{CC} ; \quad \mathrm{NAO} \text { longer } \\
\text { growth season }\end{array}$ & Northeastern Canada & Naulier et al. (2015b) \\
\hline$\delta^{13} \mathrm{C}$ & Spring-summer $T$ & Sabina przewalskii & $\begin{array}{l}\text { CC: change in cloud } \\
\text { circulation }\end{array}$ & Tibet & Wang et al. $(2016,2019)$ \\
\hline$\delta^{13} \mathrm{C}, \delta^{18} \mathrm{O}$ & VPD & Pinus ponderosa & $\mathrm{CC}$ : increase in drought & Southw. USA & Szejner et al. (2018) \\
\hline$\delta^{18} \mathrm{O}$ & Spring AO, spring NAO & Cryptomeria japonica & $\begin{array}{l}\text { CC: spring AO-EASM } \\
\text { changes }\end{array}$ & Northeastern Japan & Sakashita et al. (2018) \\
\hline$\delta^{13} \mathrm{C}$ & No link & Picea rubens & $\begin{array}{l}\text { Poll: distant } \mathrm{SO}_{2} \text { emit- } \\
\text { ters }\end{array}$ & Appalachians, USA & Mathias and Thomas (2018) \\
\hline$\delta^{18} \mathrm{O}$ & May-July $T$, RH, PDSI & Abies forrestii & $\begin{array}{l}\mathrm{CC} \text { : change in moisture } \\
\text { origin }\end{array}$ & Southwestern China & An et al. (2019) \\
\hline$\delta^{13} \mathrm{C}(\mathrm{WUE})$ & Summer $T_{\max }$ & 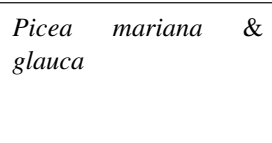 & $\begin{array}{l}\text { Poll: bitumen mining, } \\
\text { metal smelter emis- } \\
\text { sions, global } \mathrm{CO}_{2} \\
\text { rise }\end{array}$ & Alberta \& Québec, Canada & Savard et al. (2020) \\
\hline
\end{tabular}

$T$ : temperature. $T_{\max }$ : maximum temperature. RH: relative humidity. Pc: precipitation. VPD: vapour pressure deficit. AO: Arctic oscillations. NAO: North Atlantic Oscillations. PDSI: Palmer drought severity index. CC: climate change. Poll: pollution stress. EASM: East Asian summer monsoon.

\subsection{Linking isotopic time series to climatic parameters}

A preliminary word of caution on tree-ring isotopic series is that the chemical extraction of cellulose and the spectrometric measurements are critical steps. Impure cellulose and unreliable measurements may yield erroneous data, which more than likely will diverge from climate. It is understood here that dendroisotopists should make sure to follow good analytical practices (see, for instance, Loader et al., 1997; Boettger et al., 2007; Wieloch et al., 2011; Kagawa et al., 2015; Andreu-Hayles et al., 2019). 
Table 2. Summary of isotopic divergences and suggested corrective measures to use prior to climatic reconstruction.

\begin{tabular}{ll}
\hline Divergence type & Corrective and preventive measures \\
\hline Sampling and data treatment artefacts & $\begin{array}{l}\text { Mathematical modifications (correction factor, average adjustment). } \\
\text { Analysis of several stem cores from a large number of trees. }\end{array}$ \\
\hline Stand dynamics & Truncation of affected early part of the isotopic series. \\
& Mathematical removal of long trends (ex. regional curve standardization). \\
\hline Effects of rising $\mathrm{CO}_{2}$ & Ecophysiological modelling. \\
& Pre-industrial correction. \\
\hline Climate change & Truncation of divergent part of the isotopic series for calibration. \\
& Usage of latewood isotopic signals (mostly for deciduous trees). \\
& Combination of several tree-ring proxies, species or sites. \\
& Validation using independent archival systems. \\
\hline Pollution & Truncation of tree rings corresponding to period of effects. \\
& Selection of stands outside the influence area of anthropogenic emissions. \\
\hline
\end{tabular}

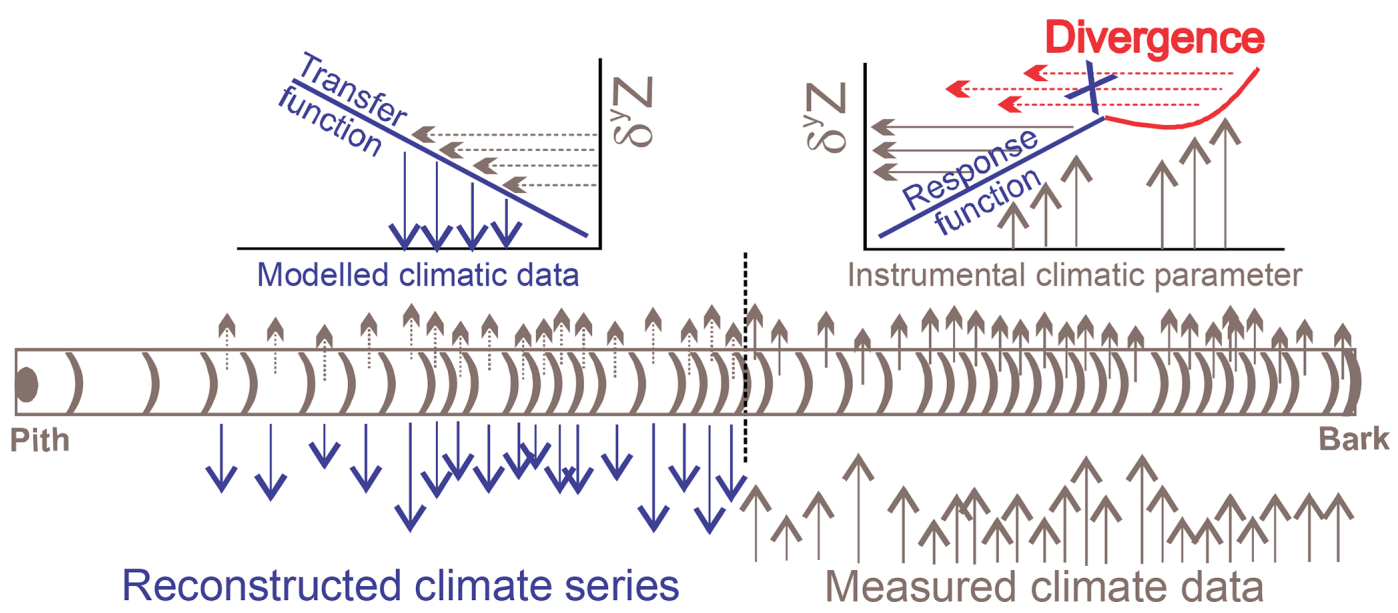

Figure 1. Schematic representation of a tree-ring isotope series used for climatic reconstruction. The statistical correlations between a climate parameter and a tree-ring isotopic proxy $\delta^{y} Z$ lead to the development of the response and transfer functions used to model climate retrospectively. Prior to reconstruction, corrective measures addressing the isotopic divergence are required.

Amongst the approaches linking the isotopic responses to meteorological variations (calibration), several statistical methods exist with various degrees of complexity, of which most assume that the relationships are linear. The strongest significant correlations between an isotopic series representative of a tree population and monthly or daily meteorological data sets adequate for the region of interest help target the climatic series for reconstruction. Multiple linear regressions constitute the most widespread statistical approach that serves to fit the relationship (response function) between the tree-ring isotopic series and the selected regional climatic data (Fig. 1). To assess the robustness of the calibration model, cross-validation techniques use subsets of the isotopic series corresponding to the meteorological instrumented period. One set serves to calibrate the climate signal (root mean squared error, RMSE; coefficient of determination, $R^{2}$ ) and the other set to validate its reconstruction ability (reduction of error, RE; coefficient of efficiency, CE; Briffa et al., 1988). The validated transfer function helps reconstruct the climatic parameter over periods when the climatic information is not available (Fig. 1).

Another methodological approach builds on the Bayesian principles for reconstructing one climatic parameter using multiple proxies over a calibration period when the set of proxies and the measured climatic parameter overlap. A model developed for each proxy estimates the likelihood of the proxy to have a specific value for a given datum of the climatic parameter (details in Tingley and Huybers, 2009; Kruschke, 2010). The prior and posterior distributions of Bayes' theorem are able to predict the climatic parameter from each proxy. This approach allows the impact of individual proxy errors to be reduced, uncertainties to be accounted for, and sensitivity tests to be run for assessing the different proxy responses to a specific forcing (Tolwinski-Ward et al., 
2013; Emile-Geay and Tingley, 2016). Combining tree-ring $\delta^{18} \mathrm{O}$ and width and density series of spruce trees from northern Québec, a Bayesian approach produced an improved millennial temperature reconstruction compared to the ones obtained from individual proxies (Gennaretti et al., 2017).

Ecophysiological models, also called vegetation, biophysical, process-based, mechanistic or tree-growth process models, relate numerous mechanisms to multiple measured foliar or tree-ring proxies (Eqs. 1-3). These models allow tree growth on a daily basis to be reproduced by integrating treering width and cellulose isotopes with daily environmental data such as minimal and maximal air temperatures, amount of precipitation, atmospheric $\mathrm{CO}_{2}$ concentration, and $\delta^{13} \mathrm{C}$ values (e.g., Ogée et al., 2009; Danis et al., 2012). The different mechanistic models have various structures, use different assumptions and calibration methods, and have differing sensitivity to climatic or non-climatic triggers (e.g., Guiot et al., 2014). Most models make forward predictions and can be used to verify that the measured tree-ring isotopic trends compare well with the isotopic outputs modelled with the meteorological and non-meteorological inputs and to identify processes behind isotopic responses. For instance, MAIDENiso is an expanded growth model which includes $\mathrm{C}$ and $\mathrm{O}$ modules. The model can reproduce the fractionation of carbon isotopes due to atmospheric $\mathrm{CO}_{2}$ diffusion to the site of carboxylation, enzymatic photosynthesis, and respiration and estimate oxygen isotopes in precipitation, soil water, and xylem water and the fractionation in leaves due to evapotranspiration and to biochemical formation of cellulose (details in Danis et al., 2012; Boucher et al., 2014; Lavergne et al., 2017). The limitations when using process-based models come from the fact that all the required daily input data are, in some cases, not measured over long periods or, in other cases, just derived, which induces uncertainties. Yet two advantages of process-based modelling for climate reconstruction are that they allow the running of a wide range of sensitivity analyses for highlighting the most influential mechanisms and that they integrate the atmospheric $\mathrm{CO}_{2}$ concentration and $\delta^{13} \mathrm{C}$ values as inputs (see also Sect. 3.3). Also considering process-based approaches, climatologists refer to the so-called proxy-system models (e.g., the Vaganov-Shashkin or VS model; Vaganov et al., 2011; Sánchez-Salguero et al., 2017). A proxy system links environment (environmental triggers) to observations as depicted by sensors (proxy responses) through models of low, intermediate or high degrees of complexity depending on the objectives and need of a specific research program (Evans et al., 2013). The tree proxy system can use tree-ring (archive) isotopes (proxy) with or without integrating other tree-ring proxies to reconstruct and interpret climate and determine the uncertainty of the results. Researchers can combine the tree proxy system with several other proxy systems such as pollens, lake sediments, corals and ice cores investigated on a local scale to perform climate modelling on a broad scale (Dee et al., 2016; Okazaki and Yoshimura, 2019).
Understanding past global climatic patterns using isotopes in trees requires producing tree-ring series from living trees and sub-fossil stems covering several centuries or millennia (e.g., Treydte et al., 2006; Gagen et al., 2011; Labuhn et al., 2014; Naulier et al., 2015b; Helama et al., 2018; GiguèreCroteau et al., 2019; Kłusek et al., 2019; Wang et al., 2016). During these long periods, climatic forcings are also in motion; they will possibly modify the dominant factors controlling isotopic responses in trees. Hence, the non-linearity of relations between tree-ring isotopes and climatic parameters due to biological functions or abiotic external changes may weaken the statistical links and create isotopic divergences. In order to produce reconstructed time series of past climate variability devoid of parts not reflecting climate reality, any approach selected for modelling the climate-isotope-based reconstruction must consider isotopic divergences.

\section{Preventable types of climate-isotope divergence}

\subsection{Departures due to sampling and data treatments}

Potential artefacts in isotopic series may arise due to sampling procedures and data treatment when building multicentury or millennial series from sub-fossil stems or timber assemblages. In this case, the selection of stems pertains to their wood quality and availability in sufficient numbers. Joining two successive cohorts of randomly picked stems may be problematic due to possible isotopic offsets between cohort averages. Shifts between cohorts, if not adjusted or adjusted improperly, can generate long-term trends in the isotopic record and yield a biased climatic reconstruction.

An approach to overcome the problem of isotopic departure between cohorts when the replication is low consists of evaluating if there are offsets between averages of successive cohorts designed to overlap over 5 years (or more if judged necessary). The next step involves calculating the isotopic means for a minimum of 10 additional individual stem segments covering the existing overlap between two successive cohorts (Gagen et al., 2012; Naulier et al., 2015a). This procedure repeated for every cohort junction was applied for joining shifted 5-year blocks of sequential pooled series, but it could apply to junctions of any cohort type, such as averaged individual series, pooled yearly sampled series or combined types (e.g., Foroozan et al., 2019). The initial junction point is set from the overlap of the youngest stem cohort with a living tree cohort. If an offset exists, the development of a linear regression permits the estimation of a factor for correcting a cohort between its two points of junction, adjusting the series from the most recent cohort to the oldest. In spruce trees from northeastern Canada, only 2 junction points out of 12 needed correction (Naulier et al., 2015a). The applicability of this correction factor method depends on the availability of a large number of stem segments, which is a particular challenge when dealing with fossil material labouriously 
collected from lakes or with construction beams from monuments where the coring allowed is strictly limited.

If the number of stem segments available for research is limited, adjusting cohorts to one another without additional individual series for calculating a factor of correction is one potential approach (Hangartner et al., 2012). One variation of this approach implies standardizing each cohort to a mean of zero and a standard deviation of one ( $z$ score). Another variation simply adjusts the average value of the older cohort to the overlap average of the newer cohort (Kress et al., 2014; Labuhn et al., 2016). The standardization method involves removing low-frequency variability that exceeds the length of the cohorts, whereas the average adjustment keeps the low-frequency records which could produce artificial longterm trends in the isotopic series (Hangartner et al., 2012). Still in the case of low availability of stem segments, another approach is to combine ring isotopic series from different sites, but this approach may induce biases that need correction through methods such as regional curve standardization (RCS; Helama et al., 2018) or other detrending methods.

Often the number of trees considered for paleoclimate reconstruction is five (e.g., Leavitt, 2008). However, one should keep in mind that the best approach for avoiding divergences due to isotopic artefacts when investigating low frequencies relevant for long-term climate reconstruction is ideally to combine several stem cores to limit artefacts due to intra-ring variability (e.g., Esper et al., 2020). In addition, studies of living trees indicate that the mean for 10 or more individual series yields adequate performances in terms of $\delta^{13} \mathrm{C}$ and $\delta^{18} \mathrm{O}$ ranges and confidence levels and preserves reliable low-frequency climatic records (Loader et al., 2013b; Daux et al., 2018). If low replication only is possible, adjustments of the composite series are required. In the end, adjusting the cohort values can overcome large divergences potentially created by using several cohorts of low replication in constructing multi-centennial series, but the possibility of false isotopic correlations with climatic parameters still persists after joining the cohorts into composite series. Note that when the pooling approach is envisaged for producing series of a specific tree species in a given region, verifying its reliability by comparison with averaged individual series is required prior to embracing the approach. This validation appears to allow the production of isotopic series devoid of methodological artefacts (Table 1).

\subsection{Height and stand dynamics}

The ambient conditions and the response of young and short trees may differ from those of more mature and, most importantly, taller trees. Generally, trees progressively evolve from the understorey to the canopy during their growth, which makes them gradually experience warmer temperature, lower humidity (higher vapour pressure deficit, VPD), better access to solar radiation and higher exposure to wind (Freiberg, 1997; Zweifel et al., 2002). This development may increase cellulose $\delta^{13} \mathrm{C}$ and $\delta^{18} \mathrm{O}$ values by enhancing the photosynthesis and transpiration rates with tree age (Banerjee and Linn, 2018). As the distance between their foliar system and the soil increases, trees leave an atmosphere containing respired ${ }^{13} \mathrm{C}$-depleted $\mathrm{CO}_{2}$. They also progressively access the open atmosphere, where $\mathrm{CO}_{2}$ is ${ }^{13} \mathrm{C}$-rich, generating a positive trend in the cellulose $\delta^{13} \mathrm{C}$ with time (Francey and Farquhar, 1982; Schleser and Jayasekera, 1985). In open canopies, the ambient conditions as trees get taller are relatively stable, and the isotopic effects described above are very likely limited to non-existent (Brienen et al., 2017; Klesse et al., 2018). However, the height increase imposes hydraulic limitation and possibly a reduction in stomatal conductance, which may lead to a rise in the cellulose $\delta^{13} \mathrm{C}$ values with age (Brienen et al., 2017, and reference herein). In certain cases, the mean depth of tree rooting may increase with the size and age of specimens, at least over the first years of growth (Weltzin and McPherson, 1997; Bouillet et al., 2002; Irvine et al., 2002; Ma et al., 2013). The absorption of an increasing proportion of a deeper, less evaporated and therefore more ${ }^{18} \mathrm{O}$-depleted source of water may result in a negative trend in cellulose $\delta^{18} \mathrm{O}$ series (Dawson, 1996). These developmental changes, and their possible impacts on $\delta^{13} \mathrm{C}$ and $\delta^{18} \mathrm{O}$ ratios, take place during the early life of the trees, when trees grow up at a maximum rate. However, the duration of this "juvenile" effect is highly variable. For instance, small and short-lived $(<0.5 \%$ over 5 years; Duffy et al., $2017)$, to moderately intense and long $\delta^{18} \mathrm{O}$ effects $(1.2 \%$ o increase over 10 years; Labuhn et al., 2014) are reported for oak cellulose. But a majority of studies conclude that there is an absence of juvenile effects on $\delta^{18} \mathrm{O}$ series (e.g., RaffalliDelerce et al., 2004; Porter et al., 2009; Daux et al., 2011; Young et al., 2011; Li et al., 2015; Kilroy et al., 2016). In contrast, juvenile effects are the norm for $\delta^{13} \mathrm{C}$ values. Many studies dealing with a variety of species and sites reported long increasing trends in the first 20-50 years of cellulose $\delta^{13} \mathrm{C}$ series (Bert et al., 1997; Duquesnay et al., 1998; Arneth et al., 2002; Li et al., 2005; Gagen, 2008; Labuhn et al., 2014), but no effect was detected in larches growing in open canopies (Daux et al., 2011; Kilroy et al., 2016). To avoid integrating possibly flawed portions in isotope-based climate reconstructions, the first 20-50 years of the isotopic series are frequently truncated (Gagen et al., 2007; Loader et al., 2013a; Labuhn et al., 2014).

In most cases, stable isotopes in tree rings do not appear to contain long-term age effects beyond the juvenile phase. Notwithstanding, several century-long $\delta^{18} \mathrm{O}$ trends were reported. For instance, negative 250-year-long trends in $J u$ niperus turkestanica from Pakistan (Treydte et al., 2006) and 400-year-long ones in Pinus uncinata from the Spanish Pyrenees (Esper et al., 2010b) were attributed to the increase in the contribution of ${ }^{18} \mathrm{O}$-depleted water from deeper soil layers as trees aged. In contrast, 150-year positive trends in Picea abies and Fagus sylvatica (central Europe; Klesse et al., 2018) were ascribed to the combined effects of enhanced 
hydraulic resistance and increased VPD as trees got taller and accessed the canopy. The distance to the upper canopy, which controls not only humidity but also light availability and therefore the photosynthetic capacity and the $\delta^{13} \mathrm{C}$ values of leaves, appears to be the best predictor of the long trends for the two mentioned species at a given site. The treering $\delta^{13} \mathrm{C}$ series of sub-fossil Pinus sylvestris from northern Fennoscandia reveal even longer trends which last throughout the tree's lifespan (Helama et al., 2015). However, some of the observed trends likely derive from the method of series construction (see Sect. 3.1), averaging isotopic data from lake sub-fossil wood of multiple sites that slightly differ in environmental conditions (Helama et al., 2018). Finally, in some cases, although there is no trend in the treering isotopic series, the response to climate in the isotopic chronologies may be age-dependent. For instance, in Picea schrenkiana from northwestern China, $\delta^{18} \mathrm{O}$ and $\delta^{13} \mathrm{C}$ values in trees under 125 years have a stronger response to relative humidity than trees older than 270 years (Xu et al., 2020). A diminishing strength of the correlations with tree age advocates for the incorporation of young trees only to develop a non-divergent composite chronology.

The biases described above may induce divergences between isotopic and climatic records. The methods frequently applied for tree-ring width and density proxies such as the RCS or other detrending procedures (i.e., negative exponential function) may help remove these divergences (Esper et al., 2010b; Helama et al., 2018). A high degree of sample replication and the avoidance of pooling are also recommended to ensure that low-frequency trends are adequately understood and characterized (Klesse et al., 2018).

\subsection{Physiological effects of rising $\mathrm{pCO}_{2}$}

Beyond the isotopic Suess effect on tree-ring $\delta^{13} \mathrm{C}$ values, industrialization has generated the largely recognized foliar physiological effect due solely to the increasing atmospheric pressure of $\mathrm{CO}_{2}$ during the 20th century. Independent of climatic conditions, this pressure effect modifies the gasexchange functions in leaves. The foliar reaction lowers $g$, or modifies $A$ and $g$ (Franks et al., 2013), and hence imprints the $\delta^{13} \mathrm{C}$ values of trees as underlined by Eqs. (1) and (2). The general direct effect is to increase the photosynthetic discrimination against ${ }^{13} \mathrm{C}$ and, as consequence, diminish the $\delta^{13} \mathrm{C}$ values of foliar sugars (e.g. Schubert and Jahren, 2012). The effects seems minimal on the tree-ring $\delta^{18} \mathrm{O}$ values (Saurer et al., 2003; Battipaglia et al., 2013). The reactions generating the lowest $\delta^{13} \mathrm{C}$ values occur if the $c_{\mathrm{i}}$ level increases proportionally with $p \mathrm{CO}_{2}\left(c_{\mathrm{at}}-c_{\mathrm{i}}\right.$ constant; passive response), and the lowest effects on the tree-ring $\delta^{13} \mathrm{C}$ values occur if $c_{\mathrm{i}} / c_{\text {at }}$ stays constant (active response; Saurer et al., 2004). The phenomenon is especially marked after 1955 - above $330 \mathrm{ppm}$ of $\mathrm{CO}_{2}-$ when the pressure rise is acute (e.g., Waterhouse et al., 2004). But cases of no isotopic responses to rising $p \mathrm{CO}_{2}$ exist as well $\left(\delta^{13} \mathrm{C}\right.$ constant; Silva and Horwath,
2013; Belmecheri et al., 2014; Wieser et al., 2016; Savard et al., 2020).

Over the last decade, the awareness of this effect on $\delta^{13} \mathrm{C}$ series has spread widely, and most scientists reconstructing climatic parameters using $\delta^{13} \mathrm{C}$ values opt to correct these ratios to minimize biased $\delta^{13} \mathrm{C}$-climate correlations (e.g., Andreu-Hayles et al., 2017). Several methods to obtain pre-industrial tree-ring $\delta^{13} \mathrm{C}$ series apply proportional corrections to rising $p \mathrm{CO}_{2}$ ranging between 0.0073 and $0.02 \%$ ppm $^{-1}$ (Feng and Epstein, 1995; Kürschner, 1996; Saurer et al., 2003; Konter et al., 2014). The performance of the proportional correction may improve by testing the reproduction of instrumental climatic series and adapting a corrective factor specific to the investigated region (Treydte et al., 2009). A widespread corrective approach uses a conditional, pre-industrial (pin) correction (Gagen et al., 2007). This six-step non-linear detrending of the low-frequency changes (McCarroll et al., 2009) works better when the measured $\delta^{13} \mathrm{C}$ series starts before or at the beginning of the industrial period (1850); otherwise the method might undercorrect the $\delta^{13} \mathrm{C}$ values (Schubert and Jahren, 2012). As in the proportional correction, the pin model assumes that the tree responses to rising $p \mathrm{CO}_{2}$ are linear and uniform even if sometimes the responses are non-linear for a given tree and heterogeneous amongst trees (Waterhouse et al., 2004; McCarroll et al., 2009). The approach pointedly applies a nonlinear regression to trees, a step that considers the $p \mathrm{CO}_{2}$ induced response specific to each tree.

However, there is no overarching consensus as to which corrective method to apply to bring $\delta^{13} \mathrm{C}$ series back to the pre-industrial level (Treydte et al., 2009; Konter et al., 2014). A wise approach is to investigate the potential influence of $p \mathrm{CO}_{2}$ on isotopic series and the gas-exchange response mechanisms in trees prior to selecting a corrective method (Voelker et al., 2016; Savard et al., 2020). In general, using the mentioned corrections removes the effects of rising $p \mathrm{CO}_{2}$ since 1850 . Exceptions to this rule can occur if rising $p \mathrm{CO}_{2}$ plays concomitantly with other natural factors such as loss of nutrients. Indeed, a case of possible nutrient loss generated an extreme active reaction to rising $p \mathrm{CO}_{2}$ and an anomalous $\delta^{13} \mathrm{C}$ series at a xeric site (Giguère-Croteau et al., 2019). An interesting recent development for addressing the $p \mathrm{CO}_{2}$-related isotopic divergence is through multiproxy ecophysiological modelling. A process-based model (MAIDENiso) applied to tree-ring width and isotopic series from oak species exemplifies this type of thorough approach, which optimizes temperature reconstructions by including increasing $p \mathrm{CO}_{2}$ directly into the model (Boucher et al., 2014).

In summary, foliar physiological reactions to rising $p \mathrm{CO}_{2}$ may generate departures in climate- $\delta^{13} \mathrm{C}$ correlations globally, but corrective methods applied routinely to calculate pre-industrial $\delta^{13} \mathrm{C}$ series largely minimize this effect, and yet the scientific community still debates on finding an unanimous corrective approach (e.g., Konter et al., 2014). The re- 
maining major problems for producing reliable, statistically reconstructed climatic series originate from two main types of isotopic divergences: climate change (long-term shift in climatic regimes) and pollution stress. Section 4 reviews the causes of these potential impeding isotopic divergences and reviews prospective avenues for correcting them (Table 2).

\section{Critical causes of climate-isotope divergence and suggested corrective measures}

\subsection{Climate change}

\subsubsection{Switching climatic controls}

Multivariate environmental factors modulate $\mathrm{C}$ and $\mathrm{O}$ isotopic fractionation in trees, and the $\delta^{18} \mathrm{O}$ and $\delta^{13} \mathrm{C}$ values of tree-ring cellulose can record these modulations. Generally, statistically significant correlations exist between the predominant factors and the isotopic records. However, the isotopic response to the climate forcing may vary over time because changes in climatic regimes regulate the relative influence of the parameters that interplay in generating treering isotopic signatures. For instance, because of the coupled and counteractive influence of moisture and temperature on the tree-ring $\delta^{13} \mathrm{C}$ values in Abies alba from the Black Forest (Germany), the $\delta^{13} \mathrm{C}$-relative humidity and $\delta^{13} \mathrm{C}$-temperature correlations depend on the temperaturehumidity relationship (Edwards et al., 2000). Therefore, for past periods with moisture-temperature relations differing from the one of the calibration period, reconstructed humidity or temperature estimates can diverge from the real values. Some environments of low moisture stress provide another good example of the effect of regime change, where tree-ring $\delta^{13} \mathrm{C}$ values depend primarily on sunshine; hence, $\delta^{13} \mathrm{C}$ relations with temperature are stable insofar as sunshine and temperature strongly correlate. Yet studies in northwestern Norway (Young et al., 2010), the northern boreal zone (Seftigen et al., 2011) and northern Spain (Dorado-Liñán et al., 2016) depicted divergences between temperature records and $\delta^{13} \mathrm{C}$ series of pine trees (Pinus sylvestris and Pinus uncinata) during episodes of decoupling between irradiance and temperature linked to either changes in large scale atmospheric circulation (first two references) or large volcanic eruptions (third reference). As illustrated in these examples, when the assumption of stationarity of the temperature-sunshine relation does not stand, reconstructing sunshine or cloudiness rather than temperature is a reliable alternative.

Modifications in atmospheric circulation, which impart changes in the origin and trajectory of cloud masses, can also induce temporal variations of the $\delta^{18} \mathrm{O}$ values of rain echoed in tree-ring cellulose at a given site and independent of climatic conditions per se (Saurer et al., 2012; Sakashita et al., 2018). Therefore, if the $\delta^{18} \mathrm{O}$ signal of the source water near trees evolves with time, the tree-ring $\delta^{18} \mathrm{O}$ series can diverge partly from the climate records. In this way, the non- stationary nature of the relationship between the tree-ring $\delta^{18} \mathrm{O}$ values of Alpine Quercus petraea (Switzerland) and climate may be ascribed to variations in moisture source determined by the dominant atmospheric circulation pattern in Europe, which is the North Atlantic Oscillation (ReynoldsHenne et al., 2007). Similarly, the weakening of the early wood $\delta^{18} \mathrm{O}$ response to climate (temperature, RH, VPD) of Abies forrestii from southwestern China may be attributable to changes in atmospheric circulation patterns linked to $\mathrm{Pa}-$ cific sea surface temperatures (An et al., 2019). Another effect of the change in source water is the modification in the strength of the linkage between the $\delta^{13} \mathrm{C}$ and $\delta^{18} \mathrm{O}$ ratios. A deterioration of this linkage was observed, for instance, in tree rings of Sabina przewalskii on the Tibetan plateau and attributed to the variation of the source water isotopic composition due to interactions between East Asian monsoons and westerly circulation (Wang et al., 2016). Hence, in that context, any correlation of $\delta^{18} \mathrm{O}$ series with climatic parameters would vary through time. As a final note, climate change through modifications of the timing and duration of the growing season owing to phenological adaptation can also modify the correlations between tree-ring $\delta^{18} \mathrm{O}$ or $\delta^{13} \mathrm{C}$ values and climate parameters as summarized below.

\subsubsection{Effects on phenology and physiology}

The effects of climate change on tree physiology are numerous and species- and site-dependent. Our objective is not to make a review of all these effects but to stress some possible physiological responses to climate change which may induce divergences between isotopic series and climatic records.

Tissue growth starts with budburst, a key process initiating the photosynthetic period. At mid-latitudes, the timing of budding and other spring phenological events of plants (leafing or flowering) largely depends on the air temperature of previous weeks and months (e.g., Defila and Clot, 2005). An effect of global warming has been to advance these spring phenological events in recent decades from several days up to about 2 weeks (e.g., Walther et al., 2002; Menzel et al., 2006; Fu et al., 2014). Some ecological studies also report delayed autumnal phenological events (growth cessation, bud set and leaf senescence; Walther et al., 2002; Menzel et al., 2006).

The first report on the sensitivity of correlations between isotopic and climatic records to phenological changes showed that ring $\delta^{13} \mathrm{C}$ series of English oak and temperature correlated optimally if temperature was averaged over a fixed-length period of $20 \mathrm{~d}$ (Aykroyd et al., 2001). Averaging used start dates varying with the second flush of leaves, i.e., using a $20 \mathrm{~d}$ period moving within July and August. This example suggests that the application of transfer functions based on isotopic correlations with climatic data of fixed periods of the year can lead to the reconstruction of climatic parameters with differing statistical significance over time depending on the strength of the relationship. In other words, isotope-climate correlations using fixed-date 
intervals may generate divergences. A few examples include divergences between summer temperature and $\delta^{13} \mathrm{C}$ series of Pinus sylvestris from eastern Finland in the second half of the 20th century (Hilasvuori et al., 2009); July-August mean temperature and $\delta^{13} \mathrm{C}$ and $\delta^{18} \mathrm{O}$ values of Larix decidua from the French Alps since the 1990s (Daux et al., 2011); and maximum summer temperature and $\delta^{18} \mathrm{O}$ values of Picea mariana in Québec (Canada) since 1995 (Naulier et al., 2015b). The overall lengthening of the growing period may also affect the relation between $\delta^{13} \mathrm{C}$ and climate series because it modifies the tree-ring $\delta^{13} \mathrm{C}$ ratio. Non-stationary relationships between temperature and precipitation with the $\delta^{13} \mathrm{C}$ series of oaks from Switzerland may derive from precocious and/or late $\mathrm{C}$ uptakes relative to the regular growing periods of trees (Reynolds-Henne et al., 2007). This interpretation invokes the seasonality of the atmospheric $\mathrm{CO}_{2} \delta^{13} \mathrm{C}$ signal (Eq. 1), which is high during summer and low during winter. During growing seasons longer than the regular ones, trees assimilate larger proportions of light C. Several consecutive years of lengthened growth seasons can thus induce long-term decreasing $\delta^{13} \mathrm{C}$ trends.

Trees use $\mathrm{C}$ through direct (assimilation from atmosphere) and indirect (internal storage) pathways to build carbohydrates during metabolic processes. At the beginning of spring, deciduous trees utilize stored starch and sugars to form early wood. After budburst, photosynthesis directly produces carbohydrates. The proportion of direct assimilates increases progressively at the expense of reconverted stored material until they are the only carbohydrate source for building new plant tissues and storing reserves mainly as starch (Carbone et al., 2013; Kimak and Leuenberger, 2015). Although evergreen conifers rely less on $\mathrm{C}$ reserves than deciduous trees, recent photosynthates supply their growth, but $\mathrm{C}$ fixed during previous years can also contribute (von Arx et al., 2017; Castagneri et al., 2018). Detecting old $\mathrm{C}$ compounds in the current year's $\mathrm{C}$ load by using wood or cellulose ${ }^{14} \mathrm{C}$ analyses highlights this contribution (Gessler and Treydte, 2016). Carbohydrate reserves are generally rich in ${ }^{13} \mathrm{C}$ relative to new photosynthates due to post-photosynthetic processes (Damesin and Lelarge, 2003; Cernusak et al., 2009; Werner and Gessler, 2011). Therefore, the use of stored $\mathrm{C}$ for trunk growth leads to higher $\delta^{13} \mathrm{C}$ in wood. The remobilization of stored $\mathrm{C}$ can thus have strong effects on the intra-annual $\delta^{13} \mathrm{C}$ signal (Offermann et al., 2011). Stress factors, such as drought and heat, impair photosynthesis and can modify the storage and remobilization patterns. Long-term exposure to drought may therefore trigger the reoccurring need to use stored $\mathrm{C}$ (Gessler and Treydte, 2016). This effect may uncouple the tree-ring $\delta^{13} \mathrm{C}$ signal from actual climate and produce divergence between the two series. Water stress can also promote the stomatal control of isotopic fractionation (Cornic, 2000). In this way, when the moist Batang-Litang plateau in western China started to experience recurrent droughts in the $1960 \mathrm{~s}$, the $\delta^{13} \mathrm{C}$ response of Abies georgei to temperature and precipitation progres- sively changed due to the gradual transition to stomatal control over the photosynthetic rate (Liu et al., 2014).

During cellulose synthesis, leaves export and exchange some $\mathrm{O}$ isotopes in sucrose with non-enriched $\mathrm{O}$ in xylem water (Sternberg et al., 1986). The fraction of $\mathrm{O}$ atoms that exchange $\left(P_{\mathrm{ex}}\right)$ equals $42 \%$ on average. However, this proportion may vary over growing seasons and longer periods due to relative humidity conditions (Gessler et al., 2009; Szejner et al., 2020b). For instance, $P_{\text {ex }}$ appears to depend on environmental conditions and phenology in Larix decidua (Gessler et al., 2013) and to increase with increasing aridity in eucalypt species (Cheesman and Cernusak, 2016; Belmecheri et al., 2018). In this last case, post-photosynthetic processes had a dampening effect on wood cellulose $\delta^{18} \mathrm{O}$ values, which induced a discrepancy between cellulose $\delta^{18} \mathrm{O}$ measurements and RH, proportional to the latter. Environmental changes (such as increasing aridity over time) may intensify post-photosynthetic exchanges, leading in time to the decoupling between cellulose $\delta^{18} \mathrm{O}$ series and climate. This little-studied cause of divergence requires further investigations.

We mentioned in Sect. 4.1.1 that divergence between climate and $\delta^{18} \mathrm{O}$ records may arise if the root water uptake deepens with tree age because deep soil layers tend to contain ${ }^{18} \mathrm{O}$-depleted water relative to surficial soil affected by evaporation. Such a deepening of rooting depth may also relate to physiological adaptation if trees need to cope with decreasing precipitation or increasing temperature (Brunner et al., 2015). Indeed, when soil-moisture declines, which often accompanies higher temperature and evaporative demand from the atmosphere, trees may have to probe down to humid layers or even to the saturated zone (Fan et al., 2017). As an example, the ring $\delta^{18} \mathrm{O}$ series of Pinus halepensis from Greece, under drought intensification, has decreased since the 1970s due to an enhanced contribution of depleted deep water to the tree's source water. This long-term $\delta^{18} \mathrm{O}$ decline was divergent from the concomitant rise in temperature (Sarris et al., 2013).

During summer middays, high VPD often reduces stomatal closure and hinders $\mathrm{CO}_{2}$ assimilation in tropical (Ishida et al., 1999), Mediterranean (Raschke and Resemann, 1986) and even cool temperate regions (Kamakura et al., 2012). As long as the yearly mean duration of the midday depression is short and varies little over time, cellulose is a trustable archive for isotope-based climate reconstruction. However, when the decline of the photosynthetic rate is severe (i.e., $60 \%$; Kets et al., 2010), a reduction of sugar production during this midday depression signifies that all daily conditions may not be imprinted in the isotopic composition of sugars and, consequently, of cellulose. If this phenomenon persists over several days during the growing season, cellulose becomes a biased, incomplete recorder of the diurnal environmental conditions. One can foresee that the global rise in temperature might exacerbate the photosynthetic midday depression, generate information loss in the cellulose isotopic 
composition and induce isotopic divergence - a phenomenon that the literature does not report yet.

\subsection{Approaches to avoid isotopic divergences due to change in climatic regimes}

Eliminating all possible causes of decoupling between isotopic and climatic records due to climate change is very challenging, but selected approaches may minimize the risks of divergence. For $\delta^{13} \mathrm{C}$-based climate reconstructions, dealing with the issue of possible effects due to remobilized $\mathrm{C}$ for trunk growth may matter. A widespread strategy consists of separating latewood from early wood whenever possible and analyzing latewood alone to avoid carry-over effects from reserves (e.g., Kagawa et al., 2006). From another angle, during wood formation, xylem cells formed by the cambium pass through successive differentiation stages, namely cell enlargement and cellulose and hemicellulose deposition into secondary cell walls, lignification and cell death (Rathgeber et al., 2016). Seasonal interactions between climate and the phenology of wood formation influence the pace and intensity of these phases (Cuny and Rathgeber, 2016). A pioneer study illustrates clearly this innovative concept, as the relations between climate drivers with $\delta^{18} \mathrm{O}$ and $\delta^{13} \mathrm{C}$ values in tree-ring subdivisions of Pinus ponderosa are best explained if lags between the initial formation of tracheids and the production of cellulosic secondary cell walls are taken into account (Belmecheri et al., 2018). Hence, integrating the rate of xylogenesis with the understanding of isotope-climate relations is a novel avenue that can help improve the interpretation of stable isotopes in tree-ring records.

For tree-ring-based climate reconstructions in general, and for identifying or eliminating divergences in particular, multi-proxy and multi-site investigations represent good alternatives. The multi-proxy approach combines two or more records of different tree-ring variables (ring width, wood density, cellulose $\delta^{13} \mathrm{C}, \delta^{18} \mathrm{O}-$ or $\delta^{2} \mathrm{H}-$ values, cell wall thickness, tracheid-lumen diameter or other wood anatomical traits) measured at the same site. Indeed, combining proxies with the same dominant control but different secondary controls tends to accentuate the common climate signal (McCarroll et al., 2011; Gennaretti et al., 2017; Wang et al., 2019). If a process generating divergence does not affect the tree-ring proxies in the same way, combining several different proxy records can help reduce the amplitude of divergence between the climate signal and its reconstruction. However, applying the multi-proxy approach may not be straightforward as a specific climate parameter may generate responses of different frequencies for different proxies. Extracting and combining responses of common frequencies are required to produce a robust climate signal (see McCarroll et al., 2011, for a discussion). The multi-site approach consists of combining records from different sites (for instance a mesic and a xeric one; Lavergne et al., 2016). In addition, one can combine the multi-site and multi-species approaches. For instance, such assemblages of isotopic records from the cellulose of Fagus sylvatica, Quercus petraea, Abies alba, Picea abies, Pinus sylvestris from several Swiss sites were shown to improve the reliability of temperature and precipitation reconstructions by cancelling out some biological noise (Saurer et al., 2008).

After going through the above options for limiting the climate-change-induced isotopic divergences, the confrontation of reconstructions from tree-ring isotopic series with independent archival systems, is a relevant approach for validating the reconstructions produced. The other archives potentially useable for such a purpose include geopotential height, ice cores, speleothems, lake sediments and historical data (Miller et al., 2006; Etien et al., 2008; Xu et al., 2016; Andreu-Hayles et al., 2017; Dinis et al., 2019; Muangsong et al., 2019; Yang et al., 2019).

\subsection{Pollution effects}

Trees are sensitive to changes in air quality, and abundant literature depicts tree-ring isotopic series recording anthropogenic pollution stress or improvement of air quality (e.g., Savard, 2010; Thomas et al., 2013; Mathias and Thomas, 2018). In such cases, the isotopic series may display longterm departures from modelled unperturbed climatic trends and an overall reduction of the tree-ring isotopic sensitivity to climatic conditions (Rinne et al., 2010; Doucet et al., 2012; Boettger et al., 2014; Savard et al., 2014). Cases of pollution effects on tree-ring $\delta^{13} \mathrm{C}$ series abound in the literature (Table 1), but only rarely do studies on this topic report significant effects on $\delta^{18} \mathrm{O}$ (or $\delta^{2} \mathrm{H}$ ) chronologies (Savard et al., 2005; Rinne et al., 2010; Boettger et al., 2014).

Pollution effects can occur in regions exposed to anthropogenic acidifying emissions, the effects of which possibly started with the earliest phase of industrialization 170 years ago, but, globally, the foremost burst of emissions occurred after the Second World War. The overall spatial and temporal extents of the pollution stress on plants closely relate to regional economic developments in industrialized countries (e.g., de Vries et al., 2014), including mining, transformation industries, transportation using hydrocarbon combustion engines and power generation based on hydrocarbon burning. The type of emitters influences the spatial extent of the pollution footprint on tree-ring isotopic series. Large smelters and coal-fired power plants with high chimneys can affect downwind trees at more than $110 \mathrm{~km}$ distance (Savard et al., $2004)$ and even remote trees $(150 \mathrm{~km}$ or more; Boettger et al., 2014), whereas emissions from highways show limited spatial reach due to the near ground level of the car exhaust (Leonelli et al., 2012). Pollutants potentially detrimental to trees are sulfur dioxide $\left(\mathrm{SO}_{2}\right)$, nitrogen oxides $\left(\mathrm{NO}_{x}\right)$, ozone $\left(\mathrm{O}_{3}\right)$, particulate matter $(\mathrm{PM})$ and volatile organic $\mathrm{C}(\mathrm{VOC})$. The degree of effects on biological functions will differ with the type and intensity of exposures to air pollutants (chemistry, chronic or short exposures and acute or mild levels). 
The effects of ozone on trees' respiration, C assimilation and stomatal conductance are complex (Matyssek et al., 2008, 2010; Grulke and Heath, 2020), and dose-response models can help predict the extent of the reactions (Agathokleous et al., 2019). Beech and spruce trees exposed to elevated $\mathrm{O}_{3}$ (and $p \mathrm{CO}_{2}$ ) in greenhouse chambers show different isotopic sensitivity to pollutants with age; amongst the tested trees, juvenile beech trees are the most sensitive of these experimental trees (Grams et al., 2007). The impacts of $\mathrm{O}_{3}$ mixed with other pollutants are difficult to predict in field conditions and even more so if hydric conditions and relative humidity are changing as well (Grulke and Heath, 2020). Documented response mechanisms of trees exposed to chronic $\mathrm{SO}_{2}$ emissions include changes in stomatal conductance, photosynthesis, dark respiration, starch production and priority of C allocation (Darrall, 1989; Meng et al., 1995; Kolb and Matyssek, 2001; Wagner and Wagner, 2006; Grams et al., 2007). With $\mathrm{SO}_{2}$, exposure at $25 \mathrm{mg} \mathrm{m}^{-3}$ induces photoinhibition and decreases $A, g$ and $C_{\mathrm{i}}$ of plants (Duan et al., 2019). The exact mechanisms responsible for closing stomata differ between $\mathrm{SO}_{2}, \mathrm{O}_{3}$ and non-harmful $\mathrm{CO}_{2}$ in terms of molecular biology. In fact, $\mathrm{O}_{3}$ and $\mathrm{CO}_{2}$ induce closure through similar mediating genes as a protection mechanism for stress avoidance and as a stimulating agent, respectively. $\mathrm{SO}_{2}$ induces closure through guard-cell mortality (Ooi et al., 2019). As seen in controlled experiments, $\mathrm{NO}_{x}$ can have species-specific positive or negative effects on trees, including opening of stomata, stimulating $\mathrm{CO}_{2}$ assimilation and increasing biomass when beneficial (Siegwolf et al., 2001), as well as reducing $g, A$ or the root-to-shoot ratios when detrimental (Siegwolf et al., 2001; Hu et al., 2015; references therein).

The response mechanisms behind the $\mathrm{C}$ and $\mathrm{O}$ isotopic fractionations in trees exposed to pollutants in controlled and field conditions are complex. When tested alone, deposition of $\mathrm{NO}_{x}$ can either increase or decrease tree-ring $\delta^{13} \mathrm{C}$ values (Siegwolf et al., 2001). $\mathrm{SO}_{2}$ and $\mathrm{O}_{3}$ may exert direct influences on $\delta^{13} \mathrm{C}$ values in leaves and sometimes indirectly on $\delta^{18} \mathrm{O}$ values (e.g., Matyssek et al., 2010; Savard, 2010). $\mathrm{SO}_{2}, \mathrm{O}_{3}$ and $\mathrm{NO}_{x}$ can also change extrinsic factors such as lowering rain $\mathrm{pH}$ and increasing soil acidity, which can in turn modify the isotopic assimilation of trees (de Vries et al., 2014; Sensuła, 2015; Yang et al., 2018). For trees that grew under the influence of $\mathrm{SO}_{2}$-dominated emissions from brick factories and coal mines, decreased $g$ and increased dark respiration and production of starch generated long-term $\delta^{13} \mathrm{C}$ increases but no significant $\delta^{18} \mathrm{O}$ changes in pine and oak trees - starch having higher $\delta^{13} \mathrm{C}$ values than cellulose (Wagner and Wagner, 2006; Rinne et al., 2010). In these cases, increased respiration rates expelled higher proportions of light $\mathrm{C}$ and generated tissues with higher $\delta^{13} \mathrm{C}$ signals without changing the $\delta^{18} \mathrm{O}$ values (Kolb and Matyssek, 2001; Wagner and Wagner, 2006). In other contexts, lower $g$ can also explain long-term $\delta{ }^{13} \mathrm{C}$ increases in coniferous trees growing near $\mathrm{SO}_{2}$ sources (e.g., Martin and Sutherland, 1990; Savard et al., 2004; Rinne et al., 2010). Concomitant lower $\delta^{2} \mathrm{H}$ (or $\delta^{18} \mathrm{O}$ ) trends in the early phases of exposure to pollutants seem coherent with extrinsic factors regulating these $\delta^{2} \mathrm{H}$ $\left(\delta^{18} \mathrm{O}\right)$ relationships inverse to the $\delta^{13} \mathrm{C}$ trends, which is coeval with drastic decreases of $c_{\mathrm{i}}$ (Savard et al., 2020). For instance, in the case of severe exposure of spruce trees to metal smelter emissions, the acidification of upper soil layers possibly induced water uptake by the remaining efficient roots at depth in soils where source water $\delta^{2} \mathrm{H}$ values are low (Savard et al., 2005). In the case of urban diffuse emissions, similar mechanisms may explain the low-frequency inverse $\delta^{13} \mathrm{C}$ and $\delta^{18} \mathrm{O}$ patterns because they are synchronous with significantly low $\mathrm{Ca} / \mathrm{Mn}$ ratios. Such conditions do not favour an increase in photosynthetic rates (Doucet et al., 2012), which is the alternative to lowering $g$ for explaining a $c_{\mathrm{i}}$ decrease in the intrinsic dual-isotopic foliar responses (Scheidegger et al., 2000).

All the described response mechanisms to airborne emissions are long term and independent of climatic effects, and they can diminish significantly the tree-ring isotope-climate correlations (Rinne et al., 2010; Boettger et al., 2014; Savard et al., 2020). As a result, pollution-influenced isotopic series enclose divergences with climatic records. Hence, using such series to develop response functions will predictably generate reconstructed climatic series which depart from the actual past climate.

\subsection{Ways to avoid isotopic divergences due to pollution}

Only a few studies have reported changes in the relationships between climatic conditions and tree-ring isotopes due to air pollutants (Table 1) and incited a careful consideration of this type of divergence prior to attempting the reconstruction of climate in a given region. The industrial time during which pollution effects could disturb the climate-isotope relationship overlaps with the periods of instrumented meteorological measurements. Interestingly, the quantification of $\mathrm{SO}_{2}$ effects on ring $\delta^{13} \mathrm{C}$ series from trees growing in field conditions reveals the complex and vain task of attempting to correct for such divergences (Rinne et al., 2010). Therefore, to avoid erroneous reconstructions using isotopic series biased due to pollution requires the removal of the part of the series corresponding to the divergence period prior to carrying out the climate-isotope calibration. This remedy may apply for regions where instrumented meteorological series are much longer than the period of disturbance, restricting the length of the tree-ring suites for isotope-climate calibration. In regions where the divergence period is too long to allow for proper statistical calibration, the only remedy is to explore remote stands not exposed to long-distance airborne pollutants. Hence, tree-ring isotopic series used for climatic reconstruction need to demonstrate that they are free of pollution effects or are truncated so as to keep only the unaffected tree-ring segments. 
Currently, mechanistic tree-growth or proxy-system models integrating isotopic results can account for several nonclimatic factors (Guiot et al., 2014), but none take into account the physiological reactions to the degradation of air quality, which would open possibilities to dodge this type of isotopic-climatic departure from stationarity. Attempting to eliminate divergences due to pollution may perhaps proceed with multi-proxy and multi-site approaches in the future (see Sect. 4.2). Clearly, at this stage of development, the most efficient way to circumvent the potential isotopic divergences between climatic parameters and isotopic series and the inconvenience of short calibration segments due to airborne pollutants is to select trees outside pollutant deposition zones.

In summary, caution should prevail when investigating trees from stands in peripheral areas of large cities, heavy industrial centres or major point sources. Emissions from such zones may have altered the tree-ring isotopic responses and the sensitivity of these proxies to climate with potentially strong effects after 1945, which is contemporaneous with latent $p \mathrm{CO}_{2}$ and climate change divergences, during the calibration period for climatic reconstruction. Screening isotopic series for pollution effects and circumventing the related isotope-climate divergences are required steps to produce valid climatic reconstructions.

\section{The isotopic divergence problem - perspective}

The sensitivity of trees to changes in their environment imparts at the same time the strengths and weakness of the treering isotopic proxies for climatic reconstruction, spurring specific proxies to record climate variations and respond to multiple triggers with varying dominance through time. Anthropogenic climate change seems to cause the observed recent disconnections between climatic parameters and isotopic variables. At longer timescales, the switching of climatic regimes and climate control on trees may be the origin of observed isotopic divergences. The reported cases of recent isotopic divergences show that foliar physiological responses to rising $p \mathrm{CO}_{2}$ and acidifying pollutants generate lower effects on $\delta^{18} \mathrm{O}$ values than on $\delta^{13} \mathrm{C}$ values and therefore suggest that $\delta^{18} \mathrm{O}$ data constitute a more appropriate proxy for reconstructing climate using statistical approaches. However, recent studies also report climate- $\delta^{18} \mathrm{O}$ divergences due to climate change, although they have lower amplitudes than those documented for $\delta^{13} \mathrm{C}$ series (Table 1). In this sense, dendroisotopists should acknowledge and fully seize the importance of isotope-climate divergences.

Following the same evolution path of recognizing treering statistical $\delta^{13} \mathrm{C}$ divergence caused by the rising $p \mathrm{CO}_{2}$ physiological effects and correcting $\delta^{13} \mathrm{C}$ series before climatic reconstruction, isotopic divergences caused by climate change and pollution need routine testing and handling when identified (Table 2). In studies conducted recently, scien- tists are addressing the issue prior to digging into a specific climatic question. For instance, early wood and latewood cross-correlations of $\delta^{13} \mathrm{C}$ and $\delta^{18} \mathrm{O}$ records in southwestern USA pine trees revealed low-frequency modes (divergence) due to climate change (Table 1). The statistical removal of these multi-year cross-correlations helped improve the relationships between isotopes and seasonal climatic data explored afterwards using a mechanistic isotope-climate forward model. The model successfully predicted different rain patterns from unimodal to bimodal precipitation from north to south (Szejner et al., 2018, 2020a).

Indeed, process-based isotopic models can serve to pinpoint causes of divergence over the last century, when measured meteorological data are available. Depending on the sophistication of the mechanistic or proxy-system approaches, modelling may even compensate for divergences due to climate change. The tree-ring isotopic outputs from process-based models are sensitive to changes in key input parameters, such as $\delta^{18} \mathrm{O}$ values in rain, vapour and soil water (Lavergne et al., 2017). Therefore, for this exact reason, inversing mechanistic models may not completely prevent producing flawed reconstructions of key parameters if changes in climatic regimes occurred during the reconstructed period. In this sense, practitioners should keep in mind that interplays of key parameters might change through time due to modulations by distant forcing. An example of such cases, as mentioned in Sect. 4.1.1, is that the assumed joint changes in tree-ring $\delta^{13} \mathrm{C}$ values and temperature were altered when the relationship between solar radiation (cloudiness) and temperature changed with cloud circulation triggered by Arctic oscillations during the last 500 years in Scandinavia (Young et al., 2010).

For dealing with isotopic divergences, again, scientists will need to adopt approaches with a level of complexity suiting their main goals. Empirical statistical modelling is practical and readily applicable but limited in its ability to reproduce the multiple physiological constraints of natural conditions. For that reason, statistical modelling may produce climatic reconstructions of variable reliability. Ecophysiological mechanistic modelling is labour intensive and theoretically powerful at the same time. In a reported comparison of the two techniques, statistical reconstructions provided precipitation and temperature series similar to the process-based inversed reconstructions (Boucher et al., 2014) owing to the strength of the statistical correlations between precipitation, temperature and the isotopic series. However, the undeniable finesse of the ecophysiological inversion comes from its incorporation of multiple proxies (ring width, $\delta^{13} \mathrm{C}$ and $\delta^{18} \mathrm{O}$ ) reflecting simultaneously several processes controlling them (Guiot et al., 2014). Another gain when working with mechanistic modelling is in getting deeper knowledge on processes controlling tree-ring properties. Nevertheless, not all model inputs (daily climatic parameters and rain $\delta^{18} \mathrm{O}$ ) are readily available or derivable, and, if available, daily records may not cover the entire calibration period (Sect. 2.2). Importantly, 
not all mechanistic models have the same readiness for climatic inversion. MAIDENiso is the only model that was successfully inversed for reconstructing climate using several proxies, including tree-ring isotopes, in three regions of the world (France, Québec and southern Argentina; Danis et al., 2012; Boucher et al., 2014; Lavergne et al., 2017). Moreover, ecophysiological models and experts with the required coding knowledge for improving the existing executable formats are rare. In addition, the complexity with process-based models resides in parametrization prior to climatic reconstruction. Therefore, depending on the availability of information, many practitioners will decide upon using statistical transfer functions and still produce very informative climatic series. In the long term, increasing the number of reconstructions worldwide, whatever the employed approach, will tend to reduce gaps and errors in reconstructed series.

The way forward in solving the isotopic divergence issue may partly come from conducting research programs using inverse process-based models simultaneously simulating meteorology, plant-life mechanisms and other non-climatic factors. In fact, process-based models continuously evolve with the addition of modules to expand their abilities. One can imagine developing and implementing modules for pollution and solar radiation that would help address some of the important issues underlined here. In closing, our main message is that reconstruction of global climatic patterns requires addressing the drawback of isotopic divergences, and the means to leap beyond this challenge reside in joining efforts from vegetation biologists, ecophysiologists, modellers, dendrochronologists, isotopists, statisticians and paleoclimatologists.

Data availability. No data sets were used in this article.

Author contributions. MMS and VD made the literature review and jointly conceived the outline of the article. MMS prepared the original draft and visualization items. VD wrote several sections.

Competing interests. The authors declare that they have no conflict of interest.

Acknowledgements. This research activity was part of the NSERC Persistence project and of the NRCan Environmental Geoscience and Climate Change programs. The authors are grateful to Étienne Boucher for stimulating discussions, Lauriane Dinis for helpful comments on an early version of the paper, and Soumaya Belmecheri for a thorough and constructive presubmission review of the article. This is NRCan contribution number 20190529.
Review statement. This paper was edited by Hans Linderholm and reviewed by two anonymous referees.

\section{References}

Agathokleous, E., Belz, R. G., Calatayud, V., De Marco, A., Hoshika, Y., Kitao, M., Saitanis, C. J., Sicard, P., Paoletti, E., and Calabrese, E. J.: Predicting the effect of ozone on vegetation via linear non-threshold (LNT), threshold and hormetic dose-response models, Sci. Total Environ., 649, 61-74, https://doi.org/10.1016/j.scitotenv.2018.08.264, 2019.

An, W., Liu, X., Hou, S., Zeng, X., Sun, W., Wang, W., Wang, Y., $\mathrm{Xu}, \mathrm{G}$., and Ren, J.: Unstable relationships between tree ring $\delta^{18} \mathrm{O}$ and climate variables over southwestern China: possible impacts from increasing central Pacific SSTs, Theor. Appl. Climatol., 136, 391-402, https://doi.org/10.1007/s00704-018-24838, 2019

Andreu-Hayles, L., Ummenhofer, C. C., Barriendos, M., Schleser, G. H., Helle, G., Leuenberger, M., Gutiérrez, E., and Cook, E. R.: 400 Years of summer hydroclimate from stable isotopes in Iberian trees, Clim. Dynam., 49, 143-161, https://doi.org/10.1007/s00382-016-3332-z, 2017.

Andreu-Hayles, L., Levesque, M., Martin-Benito, D., Huang, W., Harris, R., Oelkers, R., Leland, C., Martin-Fernández, J., Anchukaitis, K. J., and Helle, G.: A high yield cellulose extraction system for small whole wood samples and dual measurement of carbon and oxygen stable isotopes, Chem. Geol., 504, 53-65, https://doi.org/10.1016/j.chemgeo.2018.09.007, 2019.

Arneth, A., Lloyd, J., Šantrůčková, H., Bird, M., Grigoryev, S., Kalaschnikov, Y. N., Gleixner, G., and Schulze, E. D.: Response of central Siberian Scots pine to soil water deficit and long-term trends in atmospheric $\mathrm{CO}_{2}$ concentration, Global Biogeochem. Cycles, 16, 5-1-5-13, https://doi.org/10.1029/2000GB001374, 2002.

Aykroyd, R. G., Lucy, D., Pollard, A. M., Carter, A. H. C., and Robertson, I.: Temporal variability in the strength of proxy-climate correlations, Geophys. Res. Lett., 28, 1559-1562, https://doi.org/10.1029/2000GL012570, 2001.

Banerjee, T. and Linn, R.: Effect of Vertical Canopy Architecture on Transpiration, Thermoregulation and Carbon Assimilation, Forests, 9, 198, https://doi.org/10.3390/f9040198, 2018.

Barbour, M. M.: Stable oxygen isotope composition of plant tissue: a review, Funct. Plant Biol., 34, 83-94, https://doi.org/10.1071/FP06228, 2007.

Battipaglia, G., Saurer, M., Cherubini, P., Calfapietra, C., McCarthy, H. R., Norby, R. J., and Francesca Cotrufo, M.: Elevated $\mathrm{CO}_{2}$ increases tree-level intrinsic water use efficiency: Insights from carbon and oxygen isotope analyses in tree rings across three forest FACE sites, New Phytologist, 197, 544-554, https://doi.org/10.1111/nph.12044, 2013.

Belmecheri, S., Maxwell, R. S., Taylor, A. H., Davis, K. J., Freeman, K. H., and Munger, W. J.: Tree-ring $\delta^{13} \mathrm{C}$ tracks flux tower ecosystem productivity estimates in a $\mathrm{NE}$ temperate forest, Environ. Res. Lett., 9, 074011, https://doi.org/10.1088/17489326/9/7/074011, 2014.

Belmecheri, S., Wright, W. E., Szejner, P., Morino, K. A., and Monson, R. K.: Carbon and oxygen isotope fractionations in tree rings reveal interactions between cambial phenology 
and seasonal climate, Plant Cell Environ., 41, 2758-2772, https://doi.org/10.1111/pce.13401, 2018.

Bert, D., Leavitt, S. W., and Dupouey, J.-L.: Variations of wood $\delta^{13} \mathrm{C}$ and water use efficiency of Abies alba during the last century, Ecology, 78, 1588-1596, https://doi.org/10.1890/00129658(1997)078[1588:VOWCAW]2.0.CO;2, 1997.

Boettger, T., Haupt, M., Knöller, K., Weise, S. M., Waterhouse, J. S., Rinne, K. T., Loader, N. J., Sonninen, E., Jungner, H., MassonDelmotte, V., Stievenard, M., Guillemin, M.-T., Pierre, M., Pazdur, A., Leuenberger, M., Filot, M., Saurer, M., Reynolds, C. E., Helle, G., and Schleser, G. H.: Wood Cellulose Preparation Methods and Mass Spectrometric Analyses of $\delta^{13} \mathrm{C}, \delta^{18} \mathrm{O}$, and Nonexchangeable $\delta^{2} \mathrm{H}$ Values in Cellulose, Sugar, and Starch:? An Interlaboratory Comparison, Anal. Chem., 79, 4603-4612, https://doi.org/10.1021/ac0700023, 2007.

Boettger, T., Haupt, M., Friedrich, M., and Waterhouse, J. S.: Reduced climate sensitivity of carbon, oxygen and hydrogen stable isotope ratios in tree-ring cellulose of silver fir (Abies alba Mill.) influenced by background $\mathrm{SO}_{2}$ in Franconia (Germany, Central Europe), Environ. Pollut., 185, 281-294, https://doi.org/10.1016/j.envpol.2013.10.030, 2014.

Boucher, É., Guiot, J., Hatté, C., Daux, V., Danis, P.-A., and Dussouillez, P.: An inverse modeling approach for tree-ring-based climate reconstructions under changing atmospheric $\mathrm{CO}_{2}$ concentrations, Biogeosciences, 11, 3245-3258, https://doi.org/10.5194/bg-11-3245-2014, 2014.

Bouillet, J.-P., Laclau, J.-P., Arnaud, M., M'Bou, A. T., SaintAndré, L., and Jourdan, C.: Changes with age in the spatial distribution of roots of Eucalyptus clone in Congo: Impact on water and nutrient uptake, Forest Ecol. Manage., 171, 43-57, https://doi.org/10.1016/S0378-1127(02)00460-7, 2002.

Braconnot, P., Harrison, S. P., Kageyama, M., Bartlein, P. J., Masson-Delmotte, V., Abe-Ouchi, A., Otto-Bliesner, B., and Zhao, Y.: Evaluation of climate models using palaeoclimatic data, Nat. Clim. Change, 2, 417-424, https://doi.org/10.1038/nclimate1456, 2012.

Brienen, R. J. W., Gloor, E., Clerici, S., Newton, R., Arppe, L., Boom, A., Bottrell, S., Callaghan, M., Heaton, T., Helama, S., Helle, G., Leng, M. J., Mielikäinen, K., Oinonen, M., and Timonen, M.: Tree height strongly affects estimates of water-use efficiency responses to climate and $\mathrm{CO}_{2}$ using isotopes, Nat. Commun., 8, 288, https://doi.org/10.1038/s41467-017-00225-z, 2017.

Briffa, K. R., Jones, P. D., Pilcher, J. R., and Hughes, M. K.: Reconstructing Summer Temperatures in Northern Fennoscandinavia Back to A.D. 1700 Using Tree-Ring Data From Scots Pine, Arctic Alpine Res., 20, 385-394, https://doi.org/10.2307/1551336, 1988.

Briffa, K. R., Schweingruber, F. H., Jones, P. D., Osborn, T. J., Shiyatov, S. G., and Vaganov, E. A.: Reduced sensitivity of recent tree-growth to temperature at high northern latitudes, Nature, 391, 678-682, https://doi.org/10.1038/35596, 1998.

Brugnoli, E., Solomina, O., Spaccino, L., and Dolgova, E.: Climate signal in the ring width, density and carbon stable isotopes in pine (Pinus silvestris L.) in central Caucasus, Geogr. Environ. Sustainabil., 3, 4-16, https://doi.org/10.24057/2071-9388-20103-4-4-16, 2010.
Brunner, I., Herzog, C., Dawes, M. A., Arend, M., and Sperisen, C.: How tree roots respond to drought, Frontiers, 6, 547, https://doi.org/10.3389/fpls.2015.00547, 2015.

Carbone, M. S., Czimczik, C. I., Keenan, T. F., Murakami, P. F., Pederson, N., Schaberg, P. G., Xu, X., and Richardson, A. D.: Age, allocation and availability of nonstructural carbon in mature red maple trees, New Phytologist, 200, 1145-1155, https://doi.org/10.1111/nph.12448, 2013.

Castagneri, D., Battipaglia, G., von Arx, G., Pacheco, A., and Carrer, M.: Tree-ring anatomy and carbon isotope ratio show both direct and legacy effects of climate on bimodal xylem formation in Pinus pinea, Tree Physiol., 38, 1098-1109, https://doi.org/10.1093/treephys/tpy036, 2018.

Cernusak, L. A., Tcherkez, G., Keitel, C., Cornwell, W. K., Santiago, L. S., Knohl, A., Barbour, M. M., Williams, D. G., Reich, P. B., Ellsworth, D. S., Dawson, T. E., Griffiths, H. G., Farquhar, G. D., and Wright, I. J.: Why are non-photosynthetic tissues generally ${ }^{13} \mathrm{C}$ enriched compared with leaves in $\mathrm{C}_{3}$ plants? Review and synthesis of current hypotheses, Funct. Plant Biol., 36, 199213, 2009.

Cernusak, L. A., Barbour, M. M., Arndt, S. K., Cheesman, A. W., English, N. B., Feild, T. S., Helliker, B. R., Holloway-Phillips, M. M., Holtum, J. A. M., Kahmen, A., McInerney, F. A., Munksgaard, N. C., Simonin, K. A., Song, X., Stuart-Williams, H., West, J. B., and Farquhar, G. D.: Stable isotopes in leaf water of terrestrial plants, Plant Cell Environ., 39, 1087-1102, https://doi.org/10.1111/pce.12703, 2016.

Cheesman, A. W. and Cernusak, L. A.: Infidelity in the outback: climate signal recorded in $\delta^{18} \mathrm{O}$ of leaf but not branch cellulose of eucalypts across an Australian aridity gradient, Tree Physiol., 37, 554-564, https://doi.org/10.1093/treephys/tpw121, 2016.

Cornic, G.: Drought stress inhibits photosynthesis by decreasing stomatal aperture - Not by affecting ATP synthesis, Trends Plant Sci., 5, 187-188, https://doi.org/10.1016/S1360-1385(00)016253, 2000.

Cuny, H. E. and Rathgeber, C. B. K.: Xylogenesis: Coniferous Trees of Temperate Forests Are Listening to the Climate Tale during the Growing Season But Only Remember the Last Words!, Plant Physiol., 171, 306, https://doi.org/10.1104/pp.16.00037, 2016.

Damesin, C. and Lelarge, C.: Carbon isotope composition of current-year shoots from Fagus sylvatica in relation to growth, respiration and use of reserves, Plant Cell Environ., 26, 207-219, https://doi.org/10.1046/j.1365-3040.2003.00951.x, 2003.

Danis, P. A., Hatté, C., Misson, L., and Guiot, J.: MAIDENiso: a multiproxy biophysical model of tree-ring width and oxygen and carbon isotopes, Can. J. Forest Res., 42, 1697-1713, https://doi.org/10.1139/x2012-089, 2012.

Darrall, N. M.: The effect of air pollutants on physiological processes in plants, Plant Cell Environ., 12, 1-30, https://doi.org/10.1111/j.1365-3040.1989.tb01913.x, 1989.

D'Arrigo, R., Wilson, R., Liepert, B., and Cherubini, P.: On the 'Divergence Problem' in Northern Forests: A review of the tree-ring evidence and possible causes, Global Planet. Change, 60, 289305, https://doi.org/10.1016/j.gloplacha.2007.03.004, 2008.

Daux, V., Edouard, J. L., Masson-Delmotte, V., Stievenard, M., Hoffmann, G., Pierre, M., Mestre, O., Danis, P. A., and Guibal, F.: Can climate variations be inferred from tree-ring parameters and stable isotopes from Larix decidua? Juvenile effects, bud- 
moth outbreaks, and divergence issue, Earth Planet. Sc. Lett., 309, 221-233, https://doi.org/10.1016/j.eps1.2011.07.003, 2011.

Daux, V., Michelot-Antalik, A., Lavergne, A., Pierre, M., Stievenard, M., Bréda, N., and Damesin, C.: Comparisons of the Performance of $\delta^{13} \mathrm{C}$ and $\delta^{18} \mathrm{O}$ of Fagus sylvatica, Pinus sylvestris, and Quercus petraea in the Record of Past Climate Variations, J. Geophys. Res.-Biogeo., 123, 1145-1160, https://doi.org/10.1002/2017JG004203, 2018.

Dawson, T. E.: Determining water use by trees and forests from isotopic, energy balance and transpiration analyses: the roles of tree size and hydraulic lift, Tree Physiol., 16, 263-272, https://doi.org/10.1093/treephys/16.1-2.263, 1996.

Dee, S. G., Steiger, N. J., Emile-Geay, J., and Hakim, G. J.: On the utility of proxy system models for estimating climate states over the common era, J. Adv. Model. Earth Syst., 8, 1164-1179, https://doi.org/10.1002/2016MS000677, 2016.

Defila, C. and Clot, B.: Phytophenological trends in the Swiss Alps, 1951-2002, Meteorol. Z., 14, 191-196, https://doi.org/10.1127/0941-2948/2005/0021, 2005.

de Vries, W., Dobbertin, M. H., Solberg, S., van Dobben, H. F., and Schaub, M.: Impacts of acid deposition, ozone exposure and weather conditions on forest ecosystems in Europe: an overview, Plant Soil, 380, 1-45, https://doi.org/10.1007/s11104-014-20562, 2014.

Di Matteo, G., De Angelis, P., Brugnoli, E., Cherubini, P., and Scarascia-Mugnozza, G.: Tree-ring $\delta^{13} \mathrm{C}$ reveals the impact of past forest management on water-use efficiency in a Mediterranean oak coppice in Tuscany (Italy), Ann. Forest Sci., 67, 510 510, https://doi.org/10.1051/forest/2010012, 2010.

Dinis, L., Bégin, C., Savard, M. M., Marion, J., Brigode, P., and Alvarez, C. J. C. D.: Tree-ring stable isotopes for regional discharge reconstruction in eastern Labrador and teleconnection with the Arctic Oscillation, Clim. Dynam., 53, 3625-3640, https://doi.org/10.1007/s00382-019-04731-2, 2019.

Dorado-Liñán, I., Sanchez-Lorenzo, A., Gutiérrez Merino, E., Planells, O., Heinrich, I., Helle, G., and Zorita, E.: Changes in surface solar radiation in Northeastern Spain over the past six centuries recorded by tree-ring $\delta^{13} \mathrm{C}$, Clim. Dynam., 47, 937950, https://doi.org/10.1007/s00382-015-2881-x, 2016.

Doucet, A., Savard, M. M., Bégin, C., Marion, J., Smirnoff, A., and Ouarda, T. B. M. J.: Combining tree-ring metal concentrations and lead, carbon and oxygen isotopes to reconstruct peri-urban atmospheric pollution, Tellus B, 64, 19005, https://doi.org/10.3402/tellusb.v64i0.19005, 2012.

Duan, J., Fu, B., Kang, H., Song, Z., Jia, M., Cao, D., and Wei, A.: Response of gas-exchange characteristics and chlorophyll fluorescence to acute sulfur dioxide exposure in landscape plants, Ecotox. Environ. Safe., 171, 122-129, https://doi.org/10.1016/j.ecoenv.2018.12.064, 2019.

Duffy, J. E., McCarroll, D., Barnes, A., Bronk Ramsey, C., Davies, D., Loader, N. J., Miles, D., and Young, G. H. F.: Short-lived juvenile effects observed in stable carbon and oxygen isotopes of UK oak trees and historic building timbers, Chem. Geol., 472, 1-7, https://doi.org/10.1016/j.chemgeo.2017.09.007, 2017.

Duquesnay, A., Bréda, N., Stievenard, M., and Dupouey, J. L.: Changes of tree-ring $\delta^{13} \mathrm{C}$ and water-use efficiency of beech ( $\mathrm{Fa}$ gus sylvatica L.) in north-eastern France during the past century, Plant Cell Enviro., 21, 565-572, https://doi.org/10.1046/j.13653040.1998.00304.x, 1998.
Edwards, T. W. D., Graf, W., Trimborn, P., Stichler, W., Lipp, J., and Payer, H. D.: $\delta^{13} \mathrm{C}$ response surface resolves humidity and temperature signals in trees, Geochim. Cosmochim. Ac., 64, 161167, https://doi.org/10.1016/S0016-7037(99)00289-6, 2000.

Emile-Geay, J. and Tingley, M.: Inferring climate variability from nonlinear proxies: application to palaeo-ENSO studies, Clim Past, 12, 31-50, https://doi.org/10.5194/cp-12-31-2016, 2016.

Esper, J. and Frank, D.: Divergence pitfalls in tree-ring research, Clim. Change, 94, 261, https://doi.org/10.1007/s10584009-9594-2, 2009.

Esper, J., Frank, D., Büntgen, U., Verstege, A., Hantemirov, R., and Kirdyanov, A. V.: Trends and uncertainties in Siberian indicators of 20th century warming, Global Change Biol., 16, 386-398, https://doi.org/10.1111/j.1365-2486.2009.01913.x, 2010a.

Esper, J., Frank, D. C., Battipaglia, G., Büntgen, U., Holert, C., Treydte, K., Siegwolf, R., and Saurer, M.: Low-frequency noise in $\delta^{13} \mathrm{C}$ and $\delta^{18} \mathrm{O}$ tree ring data: A case study of Pinus uncinata in the Spanish Pyrenees, Global Biogeochem. Cycles, 24, GB4018, https://doi.org/10.1029/2010GB003772, 2010b.

Esper, J., Riechelmann, F. C. D., and Holzkämper, S.: Circumferential and Longitudinal $\delta^{13} \mathrm{C}$ Variability in a Larix decidua Trunk from the Swiss Alps, Forests, 11, 117, https://doi.org/10.3390/f11010117, 2020.

Etien, N., Daux, V., Masson-Delmotte, V., Stievenard, M., Bernard, V., Durost, S., Guillemin, M. T., Mestre, O., and Pierre, M.: A bi-proxy reconstruction of Fontainebleau (France) growing season temperature from A.D. 1596 to 2000, Clim. Past, 4, 91-106, https://doi.org/10.5194/cp-4-91-2008, 2008.

Evans, M. N., Tolwinski-Ward, S. E., Thompson, D. M., and Anchukaitis, K. J.: Applications of proxy system modeling in high resolution paleoclimatology, Quaternary Sci. Rev., 76, 16-28, https://doi.org/10.1016/j.quascirev.2013.05.024, 2013.

Fan, Y., Miguez-Macho, G., Jobbágy, E. G., Jackson, R. B., and Otero-Casal, C.: Hydrologic regulation of plant rooting depth, P. Natl. Acad. Sci. USA, 114, 10572, https://doi.org/10.1073/pnas.1712381114, 2017.

Farquhar, G. D., Ehleringer, J. R., and Hubick, K. T.: Carbon isotope discrimination and photosynthesis, Annu. Rev. Plant Physiol. Plant Mol. Biol., 40, 503-537, 1989.

Feng, X. and Epstein, S.: Carbon isotopes of trees from arid environments and implications for reconstructing atmospheric $\mathrm{CO}_{2}$ concentration, Geochim. Cosmochim. Ac., 59, 2599-2608, https://doi.org/10.1016/0016-7037(95)00152-2, 1995.

Foroozan, Z., Grießinger, J., Pourtahmasi, K., and Bräuning, A.: Evaluation of Different Pooling Methods to Establish a Multi-Century $\delta^{18} \mathrm{O}$ Chronology for Paleoclimate Reconstruction, Geosciences, 9, 270, https://doi.org/10.3390/geosciences9060270, 2019.

Francey, R. J. and Farquhar, G. D.: An explanation of ${ }^{13} \mathrm{C} /{ }^{12} \mathrm{C}$ variations in tree rings, Nature, 297, 28-31, https://doi.org/10.1038/297028a0, 1982.

Franks, P. J., Adams, M. A., Amthor, J. S., Barbour, M. M., Berry, J. A., Ellsworth, D. S., Farquhar, G. D., Ghannoum, O., Lloyd, J., McDowell, N., Norby, R. J., Tissue, D. T., and von Caemmerer, S.: Sensitivity of plants to changing atmospheric $\mathrm{CO}_{2}$ concentration: from the geological past to the next century, New Phytologist, 197, 1077-1094, https://doi.org/10.1111/nph.12104, 2013. 
Freiberg, M.: Spatial and temporal pattern of temperature and humidity of a tropical premontane rain forest tree in Costa Rica, Selbyana, 18, 77-84, 1997.

Fu, Y. H., Piao, S., Op de Beeck, M., Cong, N., Zhao, H., Zhang, Y., Menzel, A., and Janssens, I. A.: Recent spring phenology shifts in western Central Europe based on multiscale observations, Global Ecol. Biogeogr., 23, 1255-1263, https://doi.org/10.1111/geb.12210, 2014.

Gagen, M.: Do tree ring $\delta^{13} \mathrm{C}$ series from Pinus sylvestris in northern Fennoscandia contain longterm non-climatic trends?, Chem. Geol., 252, 42-51, https://doi.org/10.1016/j.chemgeo.2008.01.013, 2008.

Gagen, M., McCarroll, D., and Edouard, J.-L.: Combining Ring Width, Density and Stable Carbon Isotope Proxies to Enhance the Climate Signal in Tree-Rings: An Example from the Southern French Alps, Clim. Change, 78, 363-379, https://doi.org/10.1007/s10584-006-9097-3, 2006.

Gagen, M., McCarroll, D., Loader, N. J., Robertson, I., Jalkanen, R., and Anchukaitis, K. J.: Exorcising the "segment length curse": summer temperature reconstruction since AD 1640 using non-detrended stable carbon isotope ratios from pine trees in northern Finland, Holocene, 17, 435-446, https://doi.org/10.1177/0959683607077012, 2007.

Gagen, M., Zorita, E., McCarroll, D., Young, G. H. F., Grudd, H., Jalkanen, R., Loader, N. J., Robertson, I., and Kirchhefer, A.: Cloud response to summer temperatures in Fennoscandia over the last thousand years, Geophys. Res. Lett., 38, L05701, https://doi.org/10.1029/2010GL046216, 2011.

Gagen, M., McCarroll, D., Jalkanen, R., Loader, N. J., Robertson, I., and Young, G. H. F.: A rapid method for the production of robust millennial length stable isotope tree ring series for climate reconstruction, Global Planet. Change, 82-83, 96-103, https://doi.org/10.1016/j.gloplacha.2011.11.006, 2012.

Gennaretti, F., Huard, D., Naulier, M., Savard, M., Bégin, C., Arseneault, D., and Guiot, J.: Bayesian multiproxy temperature reconstruction with black spruce ring widths and stable isotopes from the northern Quebec taiga, Clim. Dynam., 49, 4107-4119, https://doi.org/10.1007/s00382-017-3565-5, 2017.

Gessler, A. and Treydte, K.: The fate and age of carbon - insights into the storage and remobilization dynamics in trees, New Phytologist, 209, 1338-1340, https://doi.org/10.1111/nph.13863, 2016.

Gessler, A., Brandes, E., Buchmann, N., Helle, G., Rennenberg, H., and Barnard, R. L.: Tracing carbon and oxygen isotope signals from newly assimilated sugars in the leaves to the tree-ring archive, Plant Cell Environ., 32, 780-795, https://doi.org/10.1111/j.1365-3040.2009.01957.x, 2009.

Gessler, A., Brandes, E., Keitel, C., Boda, S., Kayler, Z. E., Granier, A., Barbour, M., Farquhar, G. D., and Treydte, K.: The oxygen isotope enrichment of leaf-exported assimilates - does it always reflect lamina leaf water enrichment?, New Phytologist, 200, 144-157, https://doi.org/10.1111/nph.12359, 2013.

Gessler, A., Ferrio, J. P., Hommel, R., Treydte, K., Werner, R. A., and Monson, R. K.: Stable isotopes in tree rings: towards a mechanistic understanding of isotope fractionation and mixing processes from the leaves to the wood, Tree Physiol., 34, 796-818, https://doi.org/10.1093/treephys/tpu040, 2014.

Giguère-Croteau, C., Boucher, É., Bergeron, Y., Girardin, M. P., Drobyshev, I., Silva, L. C. R., Hélie, J.-F., and Garneau, M.:
North America's oldest boreal trees are more efficient water users due to increased $\left[\mathrm{CO}_{2}\right]$, but do not grow faster, P. Natl. Acad. Sci. USA, 116, 2749, https://doi.org/10.1073/pnas.1816686116, 2019.

Gori, Y., Camin, F., Porta, N. L., Carrer, M., and Battisti, A.: Tree rings and stable isotopes reveal the treehistory prior to insect defoliation on Norway spruce (Picea abies (L.) Karst.), Forest Ecol. Managem., 319, 99-106, https://doi.org/10.1016/j.foreco.2014.02.009, 2014.

Grams, T. E. E., Kozovits, A. R., HÄBerle, K.-H., Matyssek, R., and Dawson, T. E.: Combining $\delta^{13} \mathrm{C}$ and $\delta^{18} \mathrm{O}$ analyses to unravel competition, $\mathrm{CO}_{2}$ and $\mathrm{O}_{3}$ effects on the physiological performance of different-aged trees, Plant Cell Environ., 30, 1023 1034, https://doi.org/10.1111/j.1365-3040.2007.01696.x, 2007.

Grulke, N. E. and Heath, R. L.: Ozone effects on plants in natural ecosystems, Plant Biol., 0, 12-37, https://doi.org/10.1111/plb.12971, 2020.

Guiot, J., Boucher, E., and Gea-Izquierdo, G.: Process models and model-data fusion in dendroecology, Front. Ecol. Evol., 2, 52, https://doi.org/10.3389/fevo.2014.00052, 2014.

Hangartner, S., Kress, A., Saurer, M., Frank, D., and Leuenberger, M.: Methods to merge overlapping tree-ring isotope series to generate multi-centennial chronologies, Chem. Geol., 294-295, 127-134, https://doi.org/10.1016/j.chemgeo.2011.11.032, 2012.

Helama, S., Arppe, L., Timonen, M., Mielikäinen, K., and Oinonen, M.: Age-related trends in subfossil tree-ring $\delta^{13} \mathrm{C}$ data, Chem. Geol., 416, 28-35, https://doi.org/10.1016/j.chemgeo.2015.10.019, 2015.

Helama, S., Arppe, L., Timonen, M., Mielikäinen, K., and Oinonen, M.: A $7.5 \mathrm{ka}$ chronology of stable carbon isotopes from tree rings with implications for their use in palaeocloud reconstruction, Global Planet. Change, 170, 20-33, https://doi.org/10.1016/j.gloplacha.2018.08.002, 2018.

Hilasvuori, E., Berninger, F., Sonninen, E., Tuomenvirta, H., and Jungner, H.: Stability of climate signal in carbon and oxygen isotope records and ring width from Scots pine (Pinus sylvestris L.) in Finland, J. Quaternary Sci., 24, 469-480, https://doi.org/10.1002/jqs.1260, 2009.

Hu, Y., Bellaloui, N., Tigabu, M., Wang, J., Diao, J., Wang, K., Yang, R., and Sun, G.: Gaseous $\mathrm{NO}_{2}$ effects on stomatal behavior, photosynthesis and respiration of hybrid poplar leaves, Acta Physiol. Plant., 37, 39, https://doi.org/10.1007/s11738-0141749-8, 2015.

Irvine, J., Law, B. E., Anthoni, P. M., and Meinzer, F. C.: Water limitations to carbon exchange in old-growth and young ponderosa pine stands, Tree Physiol., 22, 189-196, https://doi.org/10.1093/treephys/22.2-3.189, 2002.

Ishida, A., Toma, T., and Marjenah: Limitation of leaf carbon gain by stomatal and photochemical processes in the top canopy of Macaranga conifera, a tropical pioneer tree, Tree Physiol., 19, 467-473, https://doi.org/10.1093/treephys/19.7.467, 1999.

Jacoby, G. C. and D'Arrigo, R. D.: Tree ring width and density evidence of climatic and potential forest change in Alaska, Global Biogeochem. Cycles, 9, 227-234, https://doi.org/10.1029/95GB00321, 1995.

Kagawa, A., Sugimoto, A., and Maximov, T. C.: ${ }^{13} \mathrm{CO}_{2}$ pulselabelling of photoassimilates reveals carbon allocation within and between tree rings, Plant Cell Environ., 29, 1571-1584, https://doi.org/10.1111/j.1365-3040.2006.01533.x, 2006. 
Kagawa, A., Sano, M., Nakatsuka, T., Ikeda, T., and Kubo, S.: An optimized method for stable isotope analysis of tree rings by extracting cellulose directly from cross-sectional laths, Chem. Geol., 393-394, 16-25, https://doi.org/10.1016/j.chemgeo.2014.11.019, 2015.

Kamakura, M., Kosugi, Y., Muramatsu, K., and Muraoka, H.: Simulations and observations of patchy stomatal behavior in leaves of Quercus crispula, a cool-temperate deciduous broad-leaved tree species, J. Plant Res., 125, 339-349, https://doi.org/10.1007/s10265-011-0460-8, 2012.

Kets, K., Darbah, J. N. T., Sober, A., Riikonen, J., Sober, J., and Karnosky, D. F.: Diurnal changes in photosynthetic parameters of Populus tremuloides, modulated by elevated concentrations of $\mathrm{CO}_{2}$ and/or $\mathrm{O}_{3}$ and daily climatic variation, Environ. Pollut., 158, 1000-1007, https://doi.org/10.1016/j.envpol.2009.09.001, 2010.

Kilroy, E., McCarroll, D., Young, G., Loader, N., and Bale, R.: Absence of juvenile effects confirmed in stable carbon and oxygen isotopes of European larch trees, Acta Silvae et Ligni, 27-33, https://doi.org/10.20315/ASetL.111.3, 2016.

Kimak, A. and Leuenberger, M.: Are carbohydrate storage strategies of trees traceable by early-latewood carbon isotope differences?, Trees, 29, 859-870, https://doi.org/10.1007/s00468-0151167-6, 2015.

Klesse, S., Weigt, R., Treydte, K., Saurer, M., Schmid, L., Siegwolf, R. T. W., and Frank, D. C.: Oxygen isotopes in tree rings are less sensitive to changes in tree size and relative canopy position than carbon isotopes, Plant Cell Environ., 41, 2899-2914, https://doi.org/10.1111/pce.13424, 2018.

Kłusek, M., Grabner, M., Pawełczyk, S., and Pawlyta, J.: An 1800year stable carbon isotope chronology based on sub-fossil wood from Lake Schwarzensee, Austria, Palaeogeogr. Palaeocl., 514, 65-76, https://doi.org/10.1016/j.palaeo.2018.10.003, 2019.

Kolb, T. E. and Matyssek, R.: Limitations and perspectives about scaling ozone impacts in trees, Environ. Pollut., 115, 373-393, https://doi.org/10.1016/S0269-7491(01)00228-7, 2001.

Konter, O., Holzkämper, S., Helle, G., Büntgen, U., Saurer, M., and Esper, J.: Climate sensitivity and parameter coherency in annually resolved $\delta^{13} \mathrm{C}$ and $\delta^{18} \mathrm{O}$ from Pinus uncinata treering data in the Spanish Pyrenees, Chem. Geol., 377, 12-19, https://doi.org/10.1016/j.chemgeo.2014.03.021, 2014.

Kress, A., Hangartner, S., Bugmann, H., Büntgen, U., Frank, D. C., Leuenberger, M., Siegwolf, R. T. W., and Saurer, M.: Swiss tree rings reveal warm and wet summers during medieval times, Geophys. Res. Lett., 41, 1732-1737, https://doi.org/10.1002/2013GL059081, 2014.

Kruschke, J. K.: Doing Bayesian Data Analysis (Second Edition), in: Doing Bayesian Data Analysis: A tutorial with R and bugs, Second edn., edited by: Kruschke, J. K., Academic Press, Boston, 529,2010

Kürschner, W. M.: Leaf stomata as biosensors of palaeoatmospheric $\mathrm{CO}_{2}$ levels, $\mathrm{PhD}$ thesis, ISBN/ISSN 90-393-1085-8, University of Groningen, Rijksuniversiteit Utrecht, 1996.

Labuhn, I., Daux, V., Pierre, M., Stievenard, M., Girardclos, O., Féron, A., Genty, D., Masson-Delmotte, V., and Mestre, O.: Tree age, site and climate controls on tree ring cellulose $\delta^{18} \mathrm{O}$ : A case study on oak trees from south-western France, Dendrochronologia, 32, 78-89, https://doi.org/10.1016/j.dendro.2013.11.001, 2014.
Labuhn, I., Daux, V., Girardclos, O., Stievenard, M., Pierre, M., and Masson-Delmotte, V.: French summer droughts since 1326 CE: a reconstruction based on tree ring cellulose $\delta^{18} \mathrm{O}$, Clim. Past, 12, 1101-1117, https://doi.org/10.5194/cp-12-1101-2016, 2016.

Lavergne, A., Daux, V., Villalba, R., Pierre, M., Stievenard, M., Vimeux, F., and Srur, A. M.: Are the oxygen isotopic compositions of Fitzroya cupressoides and Nothofagus pumilio cellulose promising proxies for climate reconstructions in northern Patagonia?, J. Geophys. Res.-Biogeo., 121, 767-776, https://doi.org/10.1002/2015JG003260, 2016.

Lavergne, A., Gennaretti, F., Risi, C., Daux, V., Boucher, E., Savard, M. M., Naulier, M., Villalba, R., Bégin, C., and Guiot, J.: Modelling tree ring cellulose $\delta^{18} \mathrm{O}$ variations in two temperaturesensitive tree species from North and South America, Clim. Past, 13, 1515-1526, https://doi.org/10.5194/cp-13-1515-2017, 2017.

Leavitt, S. W.: Tree-ring isotopic pooling without regard to mass: No difference from averaging $\delta^{13} \mathrm{C}$ values of each tree, Chem. Geol., 252, 52-55, https://doi.org/10.1016/j.chemgeo.2008.01.014, 2008.

Lee, E. H., Beedlow, P. A., Waschmann, R. S., Tingey, D. T., Cline, S., Bollman, M., Wickham, C., and Carlile, C.: Regional patterns of increasing Swiss needle cast impacts on Douglasfir growth with warming temperatures, Ecol. Evol., 7, 1116711196, https://doi.org/10.1002/ece3.3573, 2017.

Leonelli, G., Battipaglia, G., Siegwolf, R. T. W., Saurer, M., Morra di Cella, U., Cherubini, P., and Pelfini, M.: Climatic isotope signals in tree rings masked by air pollution: A case study conducted along the Mont Blanc Tunnel access road (Western Alps, Italy), Atmos. Environ., 61, 169-179, https://doi.org/10.1016/j.atmosenv.2012.07.023, 2012.

Li, Z., Nakatsuka, T., and Sano, M.: Tree-ring cellulose $\delta^{18} \mathrm{O}$ variability in pine and oak and its potential to reconstruct precipitation and relative humidity in central Japan, Geochem. J., 49, 125-137, https://doi.org/10.2343/geochemj.2.0336, 2015.

Li, Z.-H., Leavitt, S. W., Mora, C. I., and Liu, R.-M.: Influence of earlywood-latewood size and isotope differences on long-term tree-ring $\delta^{13} \mathrm{C}$ trends, Chem. Geol., 216, 191-201, https://doi.org/10.1016/j.chemgeo.2004.11.007, 2005.

Liu, X., An, W., Leavitt, S. W., Wang, W., Xu, G., Zeng, X., and Qin, D.: Recent strengthening of correlations between tree-ring $\delta^{13} \mathrm{C}$ and $\delta^{18} \mathrm{O}$ in mesic western China: Implications to climatic reconstruction and physiological responses, Global Planet. Change, 113, 23-33, https://doi.org/10.1016/j.gloplacha.2013.12.005, 2014.

Loader, N. J., Robertson, I., Barker, A. C., Switsur, V. R., and Waterhouse, J. S.: An improved technique for the batch processing of small wholewood samples to $\alpha$-cellulose, Chem. Geol., 136, 313-317, https://doi.org/10.1016/S0009-2541(96)00133-7, 1997.

Loader, N. J., Robertson, I., and McCarroll, D.: Comparison of stable carbon isotope ratios in the whole wood, cellulose and lignin of oak tree-rings, Palaeogeogr. Palaeocl., 196, 395-407, https://doi.org/10.1016/S0031-0182(03)00466-8, 2003.

Loader, N. J., Young, G. H. F., Grudd, H., and McCarroll, D.: Stable carbon isotopes from Torneträsk, northern Sweden provide a millennial length reconstruction of summer sunshine and its relationship to Arctic circulation, Quaternary Sci. Rev., 62, 97-113, https://doi.org/10.1016/j.quascirev.2012.11.014, 2013 a. 
Loader, N. J., Young, G. H. F., McCarroll, D., and Wilson, R. J. S.: Quantifying uncertainty in isotope dendroclimatology, Holocene, 23, 1221-1226, https://doi.org/10.1177/0959683613486945, 2013 b.

Ma, L.-H., Liu, X.-L., Wang, Y.-K., and Wu, P.-T.: Effects of drip irrigation on deep root distribution, rooting depth, and soil water profile of jujube in a semiarid region, Plant Soil, 373, 995-1006, https://doi.org/10.1007/s11104-013-1880-0, 2013.

Martin, B. and Sutherland, E. K.: Air pollution in the past recorded in width and stable carbon isotope composition of annual growth rings of Douglas-fir, Plant Cell Environ., 13, 839-844, https://doi.org/10.1111/j.1365-3040.1990.tb01101.x, 1990.

Mathias, J. M. and Thomas, R. B.: Disentangling the effects of acidic air pollution, atmospheric $\mathrm{CO}_{2}$, and climate change on recent growth of red spruce trees in the Central Appalachian Mountains, Global Change Biol., 24, 3938-3953, https://doi.org/10.1111/gcb.14273, 2018.

Matyssek, R., Sandermann, H., Wieser, G., Booker, F., Cieslik, S., Musselman, R., and Ernst, D.: The challenge of making ozone risk assessment for forest trees more mechanistic, Environ. Pollut., 156, 567-582, https://doi.org/10.1016/j.envpol.2008.04.017, 2008.

Matyssek, R., Karnosky, D. F., Wieser, G., Percy, K., Oksanen, E., Grams, T. E. E., Kubiske, M., Hanke, D., and Pretzsch, H.: Advances in understanding ozone impact on forest trees: Messages from novel phytotron and freeair fumigation studies, Environ. Pollut., 158, 1990-2006, https://doi.org/10.1016/j.envpol.2009.11.033, 2010.

Mayfield III, A. E., Allen, D. C., and Briggs, R. D.: Radial growth impact of pine false webworm defoliation on eastern white pine, Can. J. Forest Res., 35, 1071-1086, https://doi.org/10.1139/x05040, 2005.

McCarroll, D., Gagen, M. H., Loader, N. J., Robertson, I., Anchukaitis, K. J., Los, S., Young, G. H. F., Jalkanen, R., Kirchhefer, A., and Waterhouse, J. S.: Correction of tree ring stable carbon isotope chronologies for changes in the carbon dioxide content of the atmosphere, Geochim. Cosmochim. Ac., 73, 15391547, https://doi.org/10.1016/j.gca.2008.11.041, 2009.

McCarroll, D., Tuovinen, M., Campbell, R., Gagen, M., Grudd, H., Jalkanen, R., Loader, N. J., and Robertson, I.: A critical evaluation of multi-proxy dendroclimatology in northern Finland, J. Quaternary Sci., 26, 7-14, https://doi.org/10.1002/jqs.1408, 2011.

Meng, F.-R., Bourque, C. P. A., Belczewski, R. F., Whitney, N. J., and Arp, P. A.: Foliage responses of spruce trees to long-term low-grade sulfur dioxide deposition, Environ. Pollut., 90, 143152, https://doi.org/10.1016/0269-7491(94)00101-I, 1995.

Menzel, A., Sparks, T. H., Estrella, N., Koch, E., Aasa, A., Ahas, R., Alm-KÜBler, K., Bissolli, P., BraslavskÁ, O. G., Briede, A., Chmielewski, F. M., Crepinsek, Z., Curnel, Y., Dahl, Å., Defila, C., Donnelly, A., Filella, Y., Jatczak, K., MÅGe, F., Mestre, A., Nordli, Ø., PeÑUelas, J., Pirinen, P., RemiŠOvÁ, V., Scheifinger, H., Striz, M., Susnik, A., Van Vliet, A. J. H., Wielgolaski, F.-E., Zach, S., and Zust, A. N. A.: European phenological response to climate change matches the warming pattern, Global Change Biol., 12, 1969-1976, https://doi.org/10.1111/j.13652486.2006.01193.x, 2006.

Miller, D. L., Mora, C. I., Grissino-Mayer, H. D., Mock, C. J., Uhle, M. E., and Sharp, Z.: Tree-ring isotope records of tropical cyclone activity, P. Natl. Acad. Sci., 103, 14294, https://doi.org/10.1073/pnas.0606549103, 2006.

Muangsong, C., Cai, B., Pumijumnong, N., Lei, G., and Wang, F.: A preliminary study on teak tree ring cellulose $\delta^{18} \mathrm{O}$ from northwestern Thailand: the potential for developing multiproxy records of Thailand summer monsoon variability, Theor. Appl. Climatol., 136, 575-586, https://doi.org/10.1007/s00704-0182499-0, 2019.

Naulier, M., Savard, M. M., Bégin, C., Gennaretti, F., Arseneault, D., Marion, J., Nicault, A., and Bégin, Y.: A millennial summer temperature reconstruction for northeastern Canada using oxygen isotopes in subfossil trees, Clim. Past, 11, 1153-1164, https://doi.org/10.5194/cp-11-1153-2015, 2015a.

Naulier, M., Savard, M. M., Bégin, C., Marion, J., Nicault, A., and Bégin, Y.: Temporal instability of isotopes-climate statistical relationships - A study of black spruce trees in northeastern Canada, Dendrochronologia, 34, 33-42, https://doi.org/10.1016/j.dendro.2015.04.001, 2015b.

Offermann, C., Ferrio, J. P., Holst, J., Grote, R., Siegwolf, R., Kayler, Z., and Gessler, A.: The long way down - are carbon and oxygen isotope signals in the tree ring uncoupled from canopy physiological processes?, Tree Physiol., 31, 1088-1102, https://doi.org/10.1093/treephys/tpr093, 2011.

Ogée, J., Barbour, M. M., Wingate, L., Bert, D., Bosc, A., Stievenard, M., Lambrot, C., Pierre, M., Bariac, T., Loustau, D., and Dewar, R. C.: A single-substrate model to interpret intra-annual stable isotope signals in tree-ring cellulose, Plant Cell Environ., 32, 1071-1090, https://doi.org/10.1111/j.13653040.2009.01989.x, 2009.

Okazaki, A. and Yoshimura, K.: Global Evaluation of Proxy System Models for Stable Water Isotopes With Realistic Atmospheric Forcing, J. Geophys. Res.-Atmos., 124, 8972-8993, https://doi.org/10.1029/2018jd029463, 2019.

Ooi, L., Matsuura, T., Munemasa, S., Murata, Y., Katsuhara, M., Hirayama, T., and Mori, I. C.: The mechanism of $\mathrm{SO}_{2}$-induced stomatal closure differs from $\mathrm{O}_{3}$ and $\mathrm{CO}_{2}$ responses and is mediated by nonapoptotic cell death in guard cells, Plant Cell Environ., 42, 437-447, https://doi.org/10.1111/pce.13406, 2019.

Porter, T. J., Pisaric, M. F. J., Kokelj, S. V., and Edwards, T. W. D.: Climatic Signals in $\delta^{13} \mathrm{C}$ and $\delta^{18} \mathrm{O}$ of Tree-rings from White Spruce in the Mackenzie Delta Region, Northern Canada, Arct. Antarct. Alp. Res., 41, 497-505, https://doi.org/10.1657/19384246-41.4.497, 2009.

Raffalli-Delerce, G., Masson-Delmotte, V., Dupouey, J. L., Stievenard, M., Breda, N., and Moisselin, J. M.: Reconstruction of summer droughts using tree-ring cellulose isotopes: a calibration study with living oaks from Brittany (western France), Tellus B, 56, 160-174, https://doi.org/10.1111/j.1600-0889.2004.00086.x, 2004.

Raschke, K. and Resemann, A.: The midday depression of $\mathrm{CO}_{2}$ assimilation in leaves of Arbutus unedo L.: diurnal changes in photosynthetic capacity related to changes in temperature and humidity, Planta, 168, 546-558, https://doi.org/10.1007/BF00392275, 1986.

Rathgeber, C. B. K., Cuny, H. E., and Fonti, P.: Biological Basis of Tree-Ring Formation: A Crash Course, Front. Plant Sci., 7, 734, https://doi.org/10.3389/fpls.2016.00734, 2016.

Reynolds-Henne, C. E., Siegwolf, R. T. W., Treydte, K. S., Esper, J., Henne, S., and Saurer, M.: Temporal stability of 
climate-isotope relationships in tree rings of oak and pine (Ticino, Switzerland), Global Biogeochem. Cycles, 21, GB4009, https://doi.org/10.1029/2007gb002945, 2007.

Rinne, K. T., Loader, N. J., Switsur, V. R., Treydte, K. S., and Waterhouse, J. S.: Investigating the influence of sulphur dioxide $\left(\mathrm{SO}_{2}\right)$ on the stable isotope ratios $\left(\delta^{13} \mathrm{C}\right.$ and $\left.\delta^{18} \mathrm{O}\right)$ of tree rings, Geochim. Cosmochim. Ac., 74, 2327-2339, https://doi.org/10.1016/j.gca.2010.01.021, 2010.

Roden, J. S., Lin, G., and Ehleringer, J. R.: A mechanistic model for interpretation of hydrogen and oxygen isotope ratios in tree-ring cellulose, Geochim. Cosmochim. Ac., 64, 21-35, https://doi.org/10.1016/S0016-7037(99)00195-7, 2000.

Saffell, B. J., Meinzer, F. C., Voelker, S. L., Shaw, D. C., Brooks, J. R., Lachenbruch, B., and McKay, J.: Tree-ring stable isotopes record the impact of a foliar fungal pathogen on $\mathrm{CO}_{2}$ assimilation and growth in Douglas-fir, Plant Cell Environ., 37, 1536-1547, https://doi.org/10.1111/pce.12256, 2014.

Sakashita, W., Yokoyama, Y., Miyahara, H., Aze, T., Obrochta, S. P., Ohyama, M., and Yonenobu, H.: Assessment of Northeastern Japan Tree-Ring Oxygen Isotopes for Reconstructing Early Summer Hydroclimate and Spring Arctic Oscillation, Geochem. Geophys. Geosyst., 19, 3520-3528, https://doi.org/10.1029/2018gc007634, 2018.

Sánchez-Salguero, R., Camarero, J. J., Gutiérrez, E., González Rouco, F., Gazol, A., Sangüesa-Barreda, G., Andreu-Hayles, L., Linares, J. C., and Seftigen, K.: Assessing forest vulnerability to climate warming using a process-based model of tree growth: bad prospects for rear-edges, Global Change Biol., 23, 27052719, https://doi.org/10.1111/gcb.13541, 2017.

Sarris, D., Siegwolf, R., and Körner, C.: Inter- and intra-annual stable carbon and oxygen isotope signals in response to drought in Mediterranean pines, Agric. Forest Meteorol., 168, 59-68, https://doi.org/10.1016/j.agrformet.2012.08.007, 2013.

Saurer, M., Cherubini, P., Bonani, G., and Siegwolf, R.: Tracing carbon uptake from a natural $\mathrm{CO}_{2}$ spring into tree rings: an isotope approach, Tree Physiol., 23, 997-1004, https://doi.org/10.1093/treephys/23.14.997, 2003.

Saurer, M., Siegwolf, R. T. W., and Schweingruber, F. H.: Carbon isotope discrimination indicates improving water-use efficiency of trees in northern Eurasia over the last 100 years, Global Change Biol., 10, 2109-2120, https://doi.org/10.1111/j.13652486.2004.00869.x, 2004.

Saurer, M., Cherubini, P., Reynolds-Henne, C. E., Treydte, K. S., Anderson, W. T., and Siegwolf, R. T. W.: An investigation of the common signal in tree ring stable isotope chronologies at temperate sites, J. Geophys. Res.-Biogeo., 113, G04035, https://doi.org/10.1029/2008JG000689, 2008.

Saurer, M., Kress, A., Leuenberger, M., Rinne, K. T., Treydte, K. S., and Siegwolf, R. T. W.: Influence of atmospheric circulation patterns on the oxygen isotope ratio of tree rings in the Alpine region, J. Geophys. Res.-Atmos., 117, D05118, https://doi.org/10.1029/2011JD016861, 2012.

Savard, M., Bégin, C., Parent, M., Smirnoff, A., and Marion, J.: Effects of Smelter Sulfur Dioxide Emissions: A Spatiotemporal Perspective Using Carbon Isotopes in Tree Rings, J. Environ. Qual., 33, 13-26, https://doi.org/10.2134/jeq2004.1300, 2004.

Savard, M. M.: Tree-ring stable isotopes and historical perspectives on pollution - An overview, Environ. Pollut., 158, 2007-2013, https://doi.org/10.1016/j.envpol.2009.11.031, 2010.
Savard, M. M., Bégin, C., Smirnoff, A., Marion, J., Sharp, Z., and Parent, M.: Fractionation change of hydrogen isotopes in trees due to atmospheric pollutants, Geochim. Cosmochim. Ac., 69, 3723-3731, https://doi.org/10.1016/j.gca.2005.03.046, 2005.

Savard, M. M., Bégin, C., and Marion, J.: Modelling carbon isotopes in spruce trees reproduces air quality changes due to oil sands operations, Ecol. Indic., 45, 1-8, https://doi.org/10.1016/j.ecolind.2014.03.005, 2014.

Savard, M. M., Bégin, C., and Marion, J.: Response strategies of boreal spruce trees to anthropogenic changes in air quality and rising $p \mathrm{CO}_{2}$, Environ. Pollut., 114209, https://doi.org/10.1016/j.envpol.2020.114209, 2020.

Scheidegger, Y., Saurer, M., Bahn, M., and Siegwolf, R.: Linking stable oxygen and carbon isotopes with stomatal conductance and photosynthetic capacity: A conceptual model, Oecologia, 125, 350-357, https://doi.org/10.1007/s004420000466, 2000.

Schleser, G. H. and Jayasekera, R.: $\delta^{13} \mathrm{C}$-variations of leaves in forests as an indication of reassimilated $\mathrm{CO}_{2}$ from the soil, Oecologia, 65, 536-542, https://doi.org/10.1007/BF00379669, 1985.

Schleser, G. H., Helle, G., Lücke, A., and Vos, H.: Isotope signals as climate proxies: the role of transfer functions in the study of terrestrial archives, Quaternary Sci. Rev., 18, 927-943, https://doi.org/10.1016/S0277-3791(99)00006-2, 1999.

Schubert, B. A. and Jahren, A. H.: The effect of atmospheric $\mathrm{CO}_{2}$ concentration on carbon isotope fractionation in $\mathrm{C}_{3}$ land plants, Geochim. Cosmochim. Ac., 96, 29-43, https://doi.org/10.1016/j.gca.2012.08.003, 2012.

Seftigen, K., Linderholm, H. W., Loader, N. J., Liu, Y., and Young, G. H. F.: The influence of climate on ${ }^{13} \mathrm{C} /{ }^{12} \mathrm{C}$ and ${ }^{18} \mathrm{O} /{ }^{16} \mathrm{O}$ ratios in tree ring cellulose of Pinus sylvestris L. growing in the central Scandinavian Mountains, Chem. Geol., 286, 84-93, https://doi.org/10.1016/j.chemgeo.2011.04.006, 2011.

Sensuła, B. M.: Spatial and Short-Temporal Variability of $\delta^{13} \mathrm{C}$ and $\delta^{15} \mathrm{~N}$ and Water-Use Efficiency in Pine Needles of the Three Forests Along the Most Industrialized Part of Poland, Water Air Soil Pollut., 226, 362, https://doi.org/10.1007/s11270-015-2623z, 2015.

Siegwolf, R., Matyssek, R., Saurer, M., Maurer, S., GünthardtGoerg, M., Schmutz, P., and Bucher, J.: Stable isotope analysis reveals differential effects of soil nitrogen and nitrogen dioxide on the water use efficiency in hybrid poplar leaves, New Phytologist, 149, 233-246, https://doi.org/10.1046/j.14698137.2001.00032.x, 2001.

Silva, L. C. R. and Horwath, W. R.: Explaining Global Increases in Water Use Efficiency: Why Have We Overestimated Responses to Rising Atmospheric $\mathrm{CO}_{2}$ in Natural Forest Ecosystems?, PLoS ONE, 8, e53089, https://doi.org/10.1371/journal.pone.0053089, 2013.

Simard, S., Elhani, S., Morin, H., Krause, C., and Cherubini, P.: Carbon and oxygen stable isotopes from tree-rings to identify spruce budworm outbreaks in the boreal forest of Québec, Chem. Geol., 252, 80-87, https://doi.org/10.1016/j.chemgeo.2008.01.018, 2008.

Sternberg, L. D. S. L., Deniro, M. J., and Savidge, R. A.: Oxygen Isotope Exchange between Metabolites and Water during Biochemical Reactions Leading to Cellulose Synthesis, Plant Physiol., 82, 423, https://doi.org/10.1104/pp.82.2.423, 1986. 
Szejner, P., Wright, W. E., Belmecheri, S., Meko, D., Leavitt, S. W., Ehleringer, J. R., and Monson, R. K.: Disentangling seasonal and interannual legacies from inferred patterns of forest water and carbon cycling using tree-ring stable isotopes, Global Change Biol., 24, 5332-5347, https://doi.org/10.1111/gcb.14395, 2018.

Szejner, P., Belmecheri, S., Ehleringer, J. R., and Monson, R. K.: Recent increases in drought frequency cause observed multi-year drought legacies in the tree rings of semi-arid forests, Oecologia, 192, 241-259, https://doi.org/10.1007/s00442-019-04550-6, 2020a.

Szejner, P., Clute, T., Anderson, E., Evans, M. N., and $\mathrm{Hu}$, J.: Reduction in lumen area is associated with the $\delta^{18} \mathrm{O}$ exchange between sugars and source water during cellulose synthesis, New Phytologist, 226, 1583-1593, https://doi.org/10.1111/nph.16484, 2020b.

Thomas, R. B., Spal, S. E., Smith, K. R., and Nippert, J. B.: Evidence of recovery of Juniperus virginiana trees from sulfur pollution after the Clean Air Act, P. Natl. Acad. Sci. USA, 110, 15319, https://doi.org/10.1073/pnas.1308115110, 2013.

Tingley, M. P. and Huybers, P.: A Bayesian Algorithm for Reconstructing Climate Anomalies in Space and Time. Part I: Development and Applications to Paleoclimate Reconstruction Problems, J. Climate, 23, 2759-2781, https://doi.org/10.1175/2009JCLI3015.1, 2009.

Tolwinski-Ward, S. E., Anchukaitis, K. J., and Evans, M. N.: Bayesian parameter estimation and interpretation for an intermediate model of tree-ring width, Clim. Past, 9, 1481-1493, https://doi.org/10.5194/cp-9-1481-2013, 2013.

Treydte, K., Schleser, G., Helle, G., Frank, D., Winiger, M., Haug, G., and Esper, J.: The twentieth century was the wettest period in northern Pakistan over the past Millennium, Nature, 440, 11791182, https://doi.org/10.1038/nature04743, 2006.

Treydte, K., Frank, D., Esper, J., Andreu, L., Bednarz, Z., Berninger, F., Boettger, T., D’Alessandro, C. M., Etien, N., Filot, M., Grabner, M., Guillemin, M. T., Gutierrez, E., Haupt, M., Helle, G., Hilasvuori, E., Jungner, H., Kalela-Brundin, M., Krapiec, M., Leuenberger, M., Loader, N. J., Masson-Delmotte, V., Pazdur, A., Pawelczyk, S., Pierre, M., Planells, O., Pukiene, R., Reynolds-Henne, C. E., Rinne, K. T., Saracino, A., Saurer, M., Sonninen, E., Stievenard, M., Switsur, V. R., Szczepanek, M., Szychowska-Krapiec, E., Todaro, L., Waterhouse, J. S., Weigl, M., and Schleser, G. H.: Signal strength and climate calibration of a European tree-ring isotope network, Geophys. Res. Lett., 34, L24302, https://doi.org/10.1029/2007GL031106, 2007.

Treydte, K. S., Frank, D. C., Saurer, M., Helle, G., Schleser, G. H., and Esper, J.: Impact of climate and $\mathrm{CO}_{2}$ on a millennium-long tree-ring carbon isotope record, Geochim. Cosmochim. Ac., 73, 4635-4647, https://doi.org/10.1016/j.gca.2009.05.057, 2009.

Vaganov, E. A., Anchukaitis, K. J., and Evans, M. N.: How Well Understood Are the Processes that Create Dendroclimatic Records? A Mechanistic Model of the Climatic Control on Conifer TreeRing Growth Dynamics, in: Dendroclimatology. Developments in Paleoenvironmental Research, edited by: Hughes, M., Swetnam, T., and Diaz, H., vol. 11, Springer, Dordrecht, 2011.

Verheyden, A., Roggeman, M., Bouillon, S., Elskens, M., Beeckman, H., and Koedam, N.: Comparison between $\delta^{13} \mathrm{C}$ of $\alpha$ cellulose and bulk wood in the mangrove tree Rhizophora mucronata: Implications for dendrochemistry, Chem. Geol., 219, 275-282, https://doi.org/10.1016/j.chemgeo.2005.02.015, 2005.
Voelker, S. L., Brooks, J. R., Meinzer, F. C., Anderson, R., Bader, M. K. F., Battipaglia, G., Becklin, K. M., Beerling, D., Bert, D., Betancourt, J. L., Dawson, T. E., Domec, J.-C., Guyette, R. P., Körner, C., Leavitt, S. W., Linder, S., Marshall, J. D., Mildner, M., Ogée, J., Panyushkina, I., Plumpton, H. J., Pregitzer, K. S., Saurer, M., Smith, A. R., Siegwolf, R. T. W., Stambaugh, M. C., Talhelm, A. F., Tardif, J. C., Van de Water, P. K., Ward, J. K., and Wingate, L.: A dynamic leaf gas-exchange strategy is conserved in woody plants under changing ambient $\mathrm{CO}_{2}$ : evidence from carbon isotope discrimination in paleo and $\mathrm{CO}_{2}$ enrichment studies, Global Change Biol., 22, 889-902, https://doi.org/10.1111/gcb.13102, 2016.

von Arx, G., Arzac, A., Fonti, P., Frank, D., Zweifel, R., Rigling, A., Galiano, L., Gessler, A., and Olano, J. M.: Responses of sapwood ray parenchyma and non-structural carbohydrates of Pinus sylvestris to drought and long-term irrigation, Funct. Ecol., 31, 1371-1382, https://doi.org/10.1111/1365-2435.12860, 2017.

Wagner, R. and Wagner, E.: Influence of air pollution and site conditions on trends of carbon and oxygen isotope ratios in tree ring cellulose, Isotopes in environmental and health studies, Isot. Environ. Health S., 42, 351-365, https://doi.org/10.1080/10256010600991078, 2006.

Walther, G.-R., Post, E., Convey, P., Menzel, A., Parmesan, C., Beebee, T. J. C., Fromentin, J.-M., Hoegh-Guldberg, O., and Bairlein, F.: Ecological responses to recent climate change, Nature, 416, 389-395, https://doi.org/10.1038/416389a, 2002.

Wang, W., Liu, X., Xu, G., Zeng, X., Wu, G., Zhang, $\mathrm{X}$., and Qin, D.: Temperature signal instability of treering $\delta^{13} \mathrm{C}$ chronology in the northeastern QinghaiTibetan Plateau, Global Planet. Change, 139, 165-172, https://doi.org/10.1016/j.gloplacha.2016.02.006, 2016.

Wang, W., Liu, X., Xu, G., Treydte, K., Shao, X., Qin, D., Wang, G., and McDowell, N. G.: $\mathrm{CO}_{2}$ Fertilization Confounds Tree-Ring Records of Regional Hydroclimate at Northeastern Qinghai-Tibetan Plateau, Earth Space Sci., 6, 730-740, https://doi.org/10.1029/2018ea000529, 2019.

Waterhouse, J. S., Switsur, V. R., Barker, A. C., Carter, A. H. C., Hemming, D. L., Loader, N. J., and Robertson, I.: Northern European trees show a progressively diminishing response to increasing atmospheric carbon dioxide concentrations, Quaternary Sci. Rev., 23, 803-810, https://doi.org/10.1016/j.quascirev.2003.06.011, 2004.

Weltzin, J. F. and McPherson, G. R.: Spatial and temporal soil moisture resource partitioning by trees and grasses in a temperate savanna, Arizona, USA, Oecologia, 112, 156-164, https://doi.org/10.1007/s004420050295, 1997.

Werner, C. and Gessler, A.: Diel variations in the carbon isotope composition of respired $\mathrm{CO}_{2}$ and associated carbon sources: a review of dynamics and mechanisms, Biogeosciences, 8, 24372459, https://doi.org/10.5194/bg-8-2437-2011, 2011.

Wieloch, T., Helle, G., Heinrich, I., Voigt, M., and Schyma, P.: A novel device for batch-wise isolation of $\alpha$-cellulose from smallamount wholewood samples, Dendrochronologia, 29, 115-117, https://doi.org/10.1016/j.dendro.2010.08.008, 2011.

Wieser, G., Oberhuber, W., Gruber, A., Leo, M., Matyssek, R., and Grams, T. E. E.: Stable Water Use Efficiency under Climate Change of Three Sympatric Conifer Species at the Alpine Treeline, Front. Plant Sci., 7, 799, https://doi.org/10.3389/fpls.2016.00799, 2016. 
Xu, C., Ge, J., Nakatsuka, T., Yi, L., Zheng, H., and Sano, M.: Potential utility of tree ring $\delta^{18} \mathrm{O}$ series for reconstructing precipitation records from the lower reaches of the Yangtze River, southeast China, J. Geophys. Res.-Atmos., 121, 3954-3968, https://doi.org/10.1002/2015JD023610, 2016.

Xu, G., Wu, G., Liu, X., Chen, T., Wang, B., Hudson, A., and Trouet, V.: Age-related climate response of tree-ring $\delta^{13} \mathrm{C}$ and $\delta^{18} \mathrm{O}$ from spruce in northwestern China, with implications for relative humidity reconstructions, J. Geophys. Res.-Biogeo., 121, e2019JG005513, https://doi.org/10.1029/2019JG005513, 2020.

Yang, H. I., Park, H.-J., Lee, K.-S., Lim, S.-S., Kwak, J.-H., Lee, S.-I., Chang, S. X., Lee, S.-M., and Choi, W.-J.: $\delta^{13}$ C, $\delta^{15} \mathrm{~N}, \mathrm{~N}$ concentration, $\mathrm{C} / \mathrm{N}$, and $\mathrm{Ca} / \mathrm{Al}$ of Pinus densiflora foliage in Korean cities of different precipitation $\mathrm{pH}$ and atmospheric $\mathrm{NO}_{2}$ and $\mathrm{SO}_{2}$ levels, Ecol. Indic., 88, 27-36, https://doi.org/10.1016/j.ecolind.2018.01.020, 2018.

Yang, Y., Yang, R., Cao, J., Zhao, J., Cheng, H., and Wang, J. J. C. D.: Relationship between the Asian summer monsoon circulation and speleothem $\delta^{18} \mathrm{O}$ of Xiaobailong cave, Clim. Dynam., 53, 6351-6362, https://doi.org/10.1007/s00382-019-04935-6, 2019.
Young, G. H. F., McCarroll, D., Loader, N. J., and Kirchhefer, A. J.: A 500-year record of summer near-ground solar radiation from tree-ring stable carbon isotopes, Holocene, 20, 315-324, https://doi.org/10.1177/0959683609351902, 2010.

Young, G. H. F., Demmler, J. C., Gunnarson, B. E., Kirchhefer, A. J., Loader, N. J., and McCarroll, D.: Age trends in tree ring growth and isotopic archives: A case study of Pinus sylvestris L. from northwestern Norway, Global Biogeochem. Cycles, 25, GB2020, https://doi.org/10.1029/2010GB003913, 2011.

Zweifel, R., Böhm, J. P., and Häsler, R.: Midday stomatal closure in Norway spruce - reactions in the upper and lower crown, Tree Physiol., 22, 1125-1136, https://doi.org/10.1093/treephys/22.15$16.1125,2002$. 